NUDGING TIMELY WAGE REPORTING: FIELD EXPERIMENTAL EVIDENCE FROM THE UNITED STATES SOCIAL SUPPLEMENTARY INCOME PROGRAM

\author{
C. Yiwei Zhang \\ Jeffrey Hemmeter \\ Judd B. Kessler \\ Robert D. Metcalfe \\ Robert Weathers \\ Working Paper 27875 \\ http://www.nber.org/papers/w27875 \\ NATIONAL BUREAU OF ECONOMIC RESEARCH \\ 1050 Massachusetts Avenue \\ Cambridge, MA 02138 \\ September 2020
}

We thank Maya Shankar and the White House Social and Behavioral Sciences Team and the U.S. General Services Administration Office of Evaluation Sciences for their support of this project. The opinions, conclusions, and errors in this paper are the sole responsibility of the authors, and do not represent the social views of the Social Security Administration, the University of Pennsylvania, Boston University, the National Bureau of Economic Research, or the University of Wisconsin-Madison and do not assume endorsement by the Federal Government. The experiment in this study is registered at the AEA's Social Science Registry (RCT ID AEARCTR-0005351, available at http://www.socialscienceregistry.org/trials/5351).

NBER working papers are circulated for discussion and comment purposes. They have not been peer-reviewed or been subject to the review by the NBER Board of Directors that accompanies official NBER publications.

(C) 2020 by C. Yiwei Zhang, Jeffrey Hemmeter, Judd B. Kessler, Robert D. Metcalfe, and Robert Weathers. All rights reserved. Short sections of text, not to exceed two paragraphs, may be quoted without explicit permission provided that full credit, including $(\odot)$ notice, is given to the source. 
Nudging Timely Wage Reporting: Field Experimental Evidence from the United States Social Supplementary Income Program

C. Yiwei Zhang, Jeffrey Hemmeter, Judd B. Kessler, Robert D. Metcalfe, and Robert Weathers NBER Working Paper No. 27875

September 2020

JEL No. D04,H2

\section{$\underline{\text { ABSTRACT }}$}

We study a large-scale $(n=50,000)$ natural field experiment implemented by the U.S. Social Security Administration that was aimed at increasing the timely and accurate self-reporting of wages by Supplemental Security Income (SSI) recipients. Sending a letter reminding SSI recipients of their wage reporting responsibilities significantly increased both the likelihood of reporting any earnings and the total amount of earnings reported, though this effect decays slightly over time. However, the specific letter content-providing social information or highlighting the salience of penalties-had no systematic effect. We develop a conservative estimate that the letters generated roughly $\$ 5.91$ in savings on average per dollar spent for the U.S. government.

C. Yiwei Zhang

University of Wisconsin-Madison 1300 Linden Drive

Madison, WI 53711

cyzhang@wisc.edu

Jeffrey Hemmeter

Office of Research, Demonstration, and Employment

Social Security Administration

4303 Annex Bldg

6401 Security Blvd

Baltimore, MD 21235

jeffrey.hemmeter@ssa.gov

Judd B. Kessler

The Wharton School University

of Pennsylvania 3620 Locust

Walk Philadelphia, PA 19104

and NBER

judd.kessler@wharton.upenn.edu
Robert D. Metcalfe

Questrom School of Business

Boston University

595 Commonwealth Avenue

Boston, MA 02215

and NBER

rdmet@bu.edu

Robert Weathers

Social Security Administration

Robert.Weathers@ssa.gov

A randomized controlled trials registry entry is available at http://www.socialscienceregistry.org/trials/5351 


\section{Introduction}

Federal means-tested programs provide assistance to individuals with relatively low income and few assets, accounting for over $\$ 689$ billion in federal spending in 2015 (Congressional Budget Office 2017). In instances where cash assistance or in-kind transfers are provided on a recurring basis, these programs regularly rely on the accurate and timely self-reporting of any changes in income or other resources to ensure that benefit payments are appropriately determined and disbursed. Inaccurate and untimely reporting by beneficiaries presents a significant and ongoing policy challenge. For the Supplemental Security Income (SSI) program, the largest means-tested cash assistance program in the United States, improper benefit overpayments totaled over $\$ 3.4$ billion in fiscal year 2015 alone (Social Security Administration 2016). ${ }^{1}$

In recent years, the U.S. federal government has noted the need to reduce improper payments among agencies, particularly those that they consider to be of high-priority, such as the SSI program. ${ }^{2}$ Much of this need stems from the high costs associated with improper payments. For the SSI program, the costs of improper payments include not just the societal costs from overpayments and underpayments to recipients but also the burden placed on agency employees to identify accurate information on wages and resources for non-reporting recipients and to recover overpayments. Inaccurate reporting can pose serious consequences for recipients as well. In addition to potential reductions in future benefit payments once an overpayment has been discovered, SSI recipients may face steep financial penalties if found to have knowingly withheld information. In the event of a failure to repay the overpayment, an SSI recipient may be referred to a collections agency or have their tax refund, wages, or other benefits garnished. Additionally, once an improper payment related to earnings is discovered, the administrative process used for correcting it (e.g., paying back an overpayment months later) may dissuade an otherwise-capable individual from continuing their employment.

Economic models have typically considered how traditional policy tools such as financial incentives might motivate compliance (see Slemrod 2019). Yet misreporting persists despite the presence of financial penalties for non-compliance, with wage misreporting being the second leading cause of SSI overpayments during the fiscal years 2014 through 2018 period. $^{3}$ In the face of these challenges, there is a growing interest in leveraging

\footnotetext{
${ }^{1}$ The Office of Management and Budget (OMB) defines an improper payment as any payment that should not have been made or that was made in an incorrect amount under statutory, contractual, administrative, or other legally applicable requirements, including payments with insufficient documentation to determine if the payment was proper. Based on guidance from the OMB, any program with $\$ 750$ million in improper payments is considered a high-priority program.

${ }^{2}$ The Improper Payments Information Act of 2002, as amended by the Improper Payments Elimination and Recovery Act of 2010 and the Improper Payments Elimination and Recovery Improvement Act of 2012, requires agencies to periodically review all programs and activities and identify those that may be susceptible to significant improper payments. For those programs and activities identified as susceptible to significant improper payments, agencies must estimate the amount of improper payments and annually report this information along with details on their efforts to monitor and minimize improper payments. For reference, see https://paymentaccuracy.gov, a site established by the OMB to provide information on government-wide improper payments as well as the efforts undertaken to prevent and recover improper payments.

${ }^{3}$ See https://www.ssa.gov/improperpayments/SSI_majorCauses.html for information on the leading causes of SSI overpayments.
} 
insights from psychology and behavioral economics to conduct low-cost, quantifiable interventions aimed at "nudging" individual behavior without restricting choice or significantly changing economic incentives (Thaler and Sunstein 2008). ${ }^{4}$

In this paper, we report findings from a large-scale, randomized field experiment designed and implemented by the U.S. Social Security Administration (SSA) to study how such behavioral nudges might encourage the more accurate and timely reporting of changes in wages for the SSI program. ${ }^{5}$ Specifically, the SSA mailed SSI recipients wage reporting reminder letters (with a control group that received no letter) that varied in their inclusion of simple language, providing either 1) simple information about reporting (included on all letters), 2) social information on reporting behavior, 3) information increasing the saliency of the penalties for non-compliance, or 4) both social information and information on penalties. The SSI program provides a particularly useful setting for studying how such behavioral nudges might improve reporting compliance among beneficiaries of means-tested programs. ${ }^{6}$

We find that nudging SSI recipients with a letter reminding them of their wage reporting responsibility significantly increased both the likelihood of reporting any countable earned income and the total amount reported in the three months immediately following the mailing of the letter relative to the reporting behavior of SSI recipients who did not receive a letter. ${ }^{7}$ We observe only mild post-intervention persistence, however: the immediate relative effect of the letter decays somewhat over time. This decay appears to be in part driven by the control group of SSI recipients (i.e., those who did not receive a letter) eventually having wages on their records by the end of our observation period, albeit at a delay relative to the recipients who did receive a letter. One possible motivation for the convergence of the control group that we observe is that the SSA eventually receives and verifies earnings reports from various sources to identify unreported wages. SSI recipients who are aware of this reconciliation procedure may be motivated to report earnings. Looking over the full calendar year, SSI recipients who received a letter were on average 0.34 percentage points $(\mathrm{p}<0.10)$ more likely to have reported any earnings for the year. This represents an 11.1 percent increase relative to the control group mean. When we turn to the specific language surrounding the nudge, we find no differential effect on the likelihood of reporting any earnings from the inclusion of behaviorallymotivated messaging in the letter. That is, receiving a reminder letter increased wage reporting behavior on

\footnotetext{
${ }^{4}$ See Benartzi et al. (2017) for an overview of some key empirical studies on "nudge" interventions in policy settings and the important cost considerations necessary for evaluating the effectiveness of such interventions.

${ }^{5}$ Previous research has shown how the SSI affects people's labor supply decisions (Deshpande 2016; Kaushal 2010; Neumark and Powers 2000) and financial wellbeing (Deshpande et al. 2019)

${ }^{6}$ Given the complex rules surrounding the SSI program, both eligibility and benefit payment amounts are highly sensitive to fluctuations in income or resources, so the potential for even small shifts in behavior from a nudge to be cost-effective is quite high.

${ }^{7}$ We also provide evidence that this effect reflects a change in wage reporting behavior to the SSA, not a change in actual labor supply or earned income. In particular, in Appendix Table A.5, we show that the treatment had no effect on the likelihood of being employed, the dollar amount of W2 earnings, or the number of employers as measured by SSA data sourced from end-of-year tax returns.
} 
the extensive margin regardless of the specific behavioral framing that may have also been included in the letter.

Taken together, these findings suggest that a letter reminding SSI recipients of their wage reporting responsibilities can meaningfully influence behavior by either accelerating the timing of wage reporting relative to when wages would have otherwise been reported or inducing individuals who would have never reported wages to do so. Our intervention both lowered the incidence of overpayments and also reduced the significant costs to the SSA associated with reconciling reported and actual earnings information. This result of accelerating yield from non-pecuniary interventions is related to the experiments encouraging tax compliance in Hallsworth et al. (2017).

We assess the effectiveness of the reminder letters by comparing the direct financial costs associated with sending the reminders with the costs that the SSA would have otherwise incurred for SSI recipients who failed to report their earnings in an accurate and timely manner. Using this approach, we develop a conservative estimate that the letters generated roughly $\$ 5.91$ in savings on average per dollar spent for the SSA. While not a full social welfare evaluation, this estimate serves as a useful benchmark of the cost effectiveness of the reminder letters and suggests that not only did the reminder letters meaningfully motivate behavior, but they did so at a cost savings to the SSA.

Our paper highlights the importance of measuring experimental outcomes over longer time horizons, particularly in settings where external factors may influence the persistence of observed effects. While the appropriate time horizon will vary by context, this need for longer-term observation may be especially relevant for policy settings where the timing of reviews and other reconciliation activities can often coincide with the end of the tax or financial year. These results speak to the growing literature examining the long-run effects of nudges, which is becoming an important part of the overall cost-benefit analysis of such interventions (Allcott and Rogers 2014; Brandon et al. 2017; Choukhmane 2019; Frey and Rogers 2014; Rogers and Frey 2015).

Our paper also contributes to the broader literature on the design and use of information and nudges as new policy tools available to policymakers (e.g., Alm 2019; Bhargava and Manoli 2015; Chetty 2015; Dwenger et al. 2016; Luttmer and Singhal 2014; Perez-Truglia and Troiano 2018) and in particular, to the important behavioral literature demonstrating the value of reminders in motivating behavior (Busso et al. 2015; Chirico et al. 2019; Damgaard and Gravert 2018; Hallsworth et al. 2017; Karlan et al. 2016a, 2016b; Milkman et al. 2011). As policymakers increasingly experiment with nudges, they will need to gather more evidence about the long-run effects of these interventions on individual behavior as well as their relative cost-effectiveness (Benartzi et al. 2017).

The paper proceeds as follows. The next section provides additional background on the institutional 
setting. We then describe our data and empirical design and present our main results of how the experiment influenced wage reporting behavior. Finally, we discuss the implications of our findings, including the relative cost-effectiveness of our behavioral intervention, and conclude.

\section{Institutional Background and Motivation}

\subsection{Background on the SSI Program}

The SSI program was established in 1972 and is the largest means-tested cash assistance program in the United States, providing income support to needy blind, disabled, or aged individuals. Administered by the SSA, the program distributed nearly 55 billion dollars to over 9 million eligible recipients in 2015 (Social Security Administration 2017).

The SSI program disburses federal benefit payments to eligible recipients on a monthly basis. In addition to the benefit payments provided under the federal program, most states also offer supplementary payments. ${ }^{8}$ Both eligibility and monthly benefit amounts take into account a recipient's countable financial resources and countable income - resources and income minus any applicable exclusions - as well as a set of age, disability status, and residency requirements. ${ }^{9}$ To be considered eligible, individuals face an asset limit of $\$ 2,000$, while couples face an asset limit of $\$ 3,000$ (figures reflect 2015 unless otherwise stated). ${ }^{10}$ Those who are deemed eligible can then receive up to a maximum federal benefit of $\$ 733$ per month for an individual and $\$ 1,100$ per month for a couple. The first $\$ 20$ of monthly unearned income from nearly any source and the first $\$ 65$ of monthly earned income plus one-half remaining earnings are excluded from an individual's countable income. Any residual amount from the $\$ 20$ income exclusion applied to unearned income is applied to earned income instead. ${ }^{11}$

Under the SSI program, recipients are required to report to SSA any factors or changes in circumstances that could affect their eligibility in the program or the amount of their monthly payment. Failure to report these changes in circumstances as they arise can result in improper payments to recipients who are either no longer eligible to receive benefits or receive benefits in excess of their eligibility. While the overall rate of

\footnotetext{
${ }_{8}^{8}$ From SSA records in December 2015, approximately 1.53 million SSI recipients received a federally-administered supplementary payment from their state, with the average state supplementation being $\$ 141.80$; SSA does not track state-administered supplemental payments (Social Security Administration 2016).

${ }^{9}$ Eligibility and payment levels also depend on spousal or parental (for children) earnings and on living arrangements, specifically whether the individual or couple lives in their own household, in another's household, or in a Medicaid facility.

${ }^{10}$ Countable resources are generally defined as "cash or other liquid assets or any real or personal property that individuals (or their spouses) own and could convert to cash to be used for their support and maintenance" (Social Security Administration 2017). Exclusions to these asset limits include, but are not limited to, the value of a recipient's home, a vehicle used for transportation, and any household goods and personal effects. See Social Security Administration (2017) for additional details on resource exclusions.

${ }^{11}$ For example, an individual with wages of $\$ 535$ per month and no other sources of income would have $\$ 225$ in countable income (wages minus $\$ 85$ in income exclusions, reduced by half). The maximum federal benefit of $\$ 733$ per month is then reduced by her countable income, giving her $\$ 508$ per month in SSI benefits.
} 
payment errors is low, given the size of the SSI program and the significant dollar amounts associated with payments, even a small percentage of payment errors can add up to significant program costs. ${ }^{12}$ SSA's 2016 Agency Financial Report estimates that SSI payment errors resulted in over $\$ 3.4$ billion in overpayments in the 2015 fiscal year, which translates to roughly 6 percent of total outlays for the program (Social Security Administration 2016).

\subsection{Wage Reporting}

A major cause of improper payments in the SSI program is recipients' failure to report specifically new or increased wages in an accurate and timely manner. To initially report wages or other earnings information, an SSI recipient can contact an SSA teleservice center or report directly to an SSA Field office. ${ }^{13}$ After initially self-reporting wages, most SSI recipients can then enroll in one of two services - an automated telephone wage reporting service or a free mobile wage reporting smartphone application - to regularly report monthly wages that will affect their SSI payment amount. ${ }^{14}$

In the absence of self-reporting, an SSI recipient's wages must be determined by the SSA through other means. For SSI recipients who receive (but do not report) a monthly wage, the SSA uses data matches with either quarterly earnings data from the Office of Child Support Enforcement (OCSE) or annual earnings data from the Internal Revenue Service (IRS) to generate leads on possible wage activity. While the SSA can identify unreported wages using these two sources of data, it can generally only do so at a considerable delay from when the overpayment was made. This delay is a result of both the time it takes for earnings data from the OCSE or IRS data to be transmitted to the SSA (at which point an earnings alert is issued) and the time it takes for an SSA employee to fully develop and process the case before the wages can be posted to the SSA's primary administrative data file used for determining payment amounts. This latter task of identifying accurate wage information is especially time-consuming and places a considerable burden on SSA employees that are involved. SSA employees must contact the SSI recipient and obtain primary evidence on monthly earnings paid to them for their work activity - a process that may entail several attempts to contact the recipient, waiting for the recipient to submit primary evidence, identifying whether the recipient is eligible for work incentives, and due process notification.

\footnotetext{
${ }^{12}$ The actual rate of overpayment errors in FY2015 was just 6.06 percent, although this rate did exceed the reduction target rate of 5 percent (Social Security Administration 2016).

${ }^{13}$ As of 2016, there were over 1300 SSA Field Offices in the United States. SSI recipients are able to report wages to a Field Office either in-person, by telephone, by mail, or by fax.

${ }^{14}$ Presently, SSI recipients are also able to report wage information through an online wage reporting tool, although that option was not yet available at the time of the experiment studied in this paper.
} 


\subsection{Motivation from Behavioral Research}

Given the potential for even small improvements in timely reporting by SSI recipients to lead to substantial savings, we study a large natural field experiment implemented and designed by the SSA to evaluate the effectiveness of several behavioral nudges on wage reporting behavior by SSI recipients. There is a large literature in economics and psychology demonstrating that behavioral interventions can have significant effects on human behavior. As a result, both the private and government sectors are exploring low-cost, quantifiable interventions that leverage insights from behavioral economics to address various policy challenges by nudging individual behavior.

The main intervention that we consider in this paper is a letter reminding SSI recipients of their wage reporting responsibilities. This intervention draws on a rich behavioral literature demonstrating the value of reminders in motivating individual behavior in a wide-range of contexts, including but not limited to medical care (Busso et al. 2015; Milkman et al. 2011); financial behaviors (Karlan et al. 2016a, 2016b); tax compliance (Chirico et al. 2019; Hallsworth et al. 2017); and charitable giving (Damgaard and Gravert 2018).

In addition to exploring the effectiveness of reminders in nudging wage reporting, we investigate two additional behavioral interventions that have been shown in prior research to significantly affect behavior: a "social information" intervention and a "saliency of information" intervention. Social information interventions provide individuals with information about the actions or decisions of others. Across a variety of domains, individuals have been shown to gravitate towards taking the same behavior that they observe others take. Among many other applications: people are more likely to reduce environmentally harmful actions when they learn others are conserving (Allcott 2011; Cialdini 2003; Cialdini et al. 1990; Dolan and Metcalfe 2015; Goldstein et al. 2008); college students are more likely to donate to charity when they observe others donate (Frey and Meier 2004); recent graduates are more likely to take a teaching job when they observe others have done the same (Coffman et al. 2017); citizens are more likely to vote when they learn that others are voting (Gerber et al. 2008); and British residents are more likely to pay their taxes promptly when they learn they are in the small minority that have not yet paid (Hallsworth et al. 2017).

Alternatively, saliency of information interventions influence behavior by adjusting the attention paid to provided information. For example, low-income individuals were more likely to report earnings allowing them to take advantage of the Earned Income Tax Credit (EITC) when provided with information about the program (Chetty and Saez 2013; Chetty et al. 2013; see also Bhargava and Manoli 2015). Similarly, older Americans are more likely to work when they learn about social security (Liebman and Luttmer 2015), and unenrolled (but likely eligible) individuals are more likely to enroll in the Supplemental Nutrition Assistance Program (SNAP) when provided information about their eligibility and how to apply (Finkelstein 
and Notowidigdo 2019). Prior research has also shown that changes in the saliency of negative information, such as the costs associated with an action, can influence the likelihood of engaging in that behavior. For instance, making salient information about sales taxes leads individuals to spend less (Chetty et al. 2009) whereas individuals drive more when road tolls are paid automatically, making the cost of the tolls less salient (Finkelstein 2009).

The combination of social norms with saliency of penalties has not been previously tested. Such a test on the combination of two nudges relates to some of the earlier work on crowding-out effect of financial incentives on behavior (see Gneezy et al. 2011). More recently, there is some evidence that financial incentives and social norm information might separately affect the behavior of different types of people (List et al. 2017), and the combination of different nudges might not crowd out each other (Brandon et al. 2019)

With the above research in mind, the SSA designed and implemented an experiment in which they mailed SSI recipients wage reporting reminder letters that varied in their inclusion of simple language, including either no additional information (basic reminder) or noting other recipients' wage reporting behavior (social information), the economic penalties associated with failing to report (saliency of information), or both. By randomly mailing out these letters to SSI recipients, the experiment allows us to evaluate whether reminders, and especially reminders that include such behavioral framing, are effective in nudging recipients toward reporting wages. The two types of behavioral messaging we consider - social information and saliency of information - are of particular interest in this policy setting because of their demonstrated efficacy in nudging behavior, especially among low-income individuals, the population most likely to be targeted by federal means-tested assistance programs like the SSI.

\section{Materials and Methods}

\subsection{Data}

The primary source of data used for this field experiment is the Supplemental Security Record (SSR) master file, a confidential administrative data file containing the universe of SSI recipients. The SSR file provides demographic information, including age, race, sex, state of residence, primary spoken language, and institutionalization status, as well as program participation information, including time as recipient and whether the recipient has a representative payee. The file also includes a detailed history of monthly benefit payments, beginning from the inception of the SSI program. Importantly, the SSR includes detailed information on our main outcome of interest: the earned income for a recipient, including whether they reported any countable earnings and the dollar amount of countable earnings reported. ${ }^{15}$

\footnotetext{
${ }^{15}$ This measure reflects only the recipient's earnings and does not include spousal or parental earnings.
} 
Two important features of the data are worth noting. First, the extracts of the SSR we accessed were updated on a monthly basis: an extract from a particular month provides a snapshot of the SSR data as it exists near the end of that month. As a result, we are able to observe any changes in reported earnings information, our main outcome of interest, on a monthly basis. Second, SSI recipients are generally able to report changes in their earnings information not only for the current month but both prospectively and retroactively as well. For instance, an SSI recipient could revise their earnings information for the two months prior, even if they've already received SSI payments for those past two months. Thus, any observed response to the interventions in this experiment could be driven by changes in reported past or future earnings. We discuss the implications of these features of the data in greater detail in our discussion of the results.

\subsection{Sample Selection}

For the experiment, the SSA selected a sample of 50,000 individuals from a target population of a little over 240,000 SSI recipients who met the following conditions in 2015. First, all individuals in the sample were between 18 and 50 years of age (to increase the likelihood of earnings) with English as their primary language. To ensure that mailings would be sent directly to the SSI recipient, SSA excluded individuals who were either institutionalized or had a representative payee acting on their behalf. SSA further selected individuals who were SSI recipients for less than 6 years as research indicates new recipients are more likely to work than long-term recipients (Ben-Shalom and Stapleton 2015), who were currently receiving payments, who were living in the 50 states or Washington, DC, and who had no countable earned income posted on the SSR in the month the sample was selected. ${ }^{16}$ Since the proposed interventions were aimed at increasing compliance in wage reporting, these restrictions allowed for a focus on a target population currently without earnings but who were likely to experience changes in their earnings.

After selecting the target population, the final sample of 50,000 recipients was selected based on an internal scoring model developed by the SSA to prioritize recipients for annual "redetermination" of benefit eligibility based on their likelihood of having had a change in circumstances that would affect their monthly payment amount. ${ }^{17}$ To avoid the possibility of confounding effects from a scheduled redetermination, the SSA excluded from the sample any individual whose predicted score led to being selected for redetermination (about 2.8 million SSI recipients). The final sample consists of the 50,000 highest scoring individuals (i.e., those most likely to have had a change of circumstances affecting payment amount) of those not scheduled for redetermination who met the target population selection requirements.

Table 1 presents summary statistics and compares the characteristics of the universe of SSI recipients in

\footnotetext{
${ }^{16}$ Most SSI recipients have zero earnings.

${ }^{17}$ As part of a redetermination, the SSA reviews the income, resources, and living arrangements of a recipient to determine if they are still eligible for SSI and to confirm that they are receiving the correct payment amount.
} 
current pay status as of March 2015 (the month prior to when the letters were mailed) to the characteristics of the target population and experimental sample that we study. The differences between the two groups are largely as would be expected given the selection criteria. The experimental sample is younger, has received SSI benefits for fewer years on average, and is more likely to be classified by the SSA as a case where a medical improvement is eventually expected in comparison to the full universe of SSI recipients. The experimental sample also did not have any reported earnings in the past year, as expected from the sample selection criteria, although generally only a small fraction of SSI recipients (only 2.54 percent of the full universe of recipients in current payment status at the time of selection) ever have any earnings in the past year posted in the SSR. Additional detail on the state or territory of residence and disability type for recipients can be found in Appendix Table A.1. In general, the experimental sample is more similar to the target population than the universe of working age SSI recipients, although there are differences (comparison available upon request).

\subsection{Experimental Design}

From the experimental sample of 50,000 SSI recipients, individuals were randomly assigned to one of five groups:

1. Basic Intervention - a group that was sent a form letter reminding them of the need to report any information about earnings that might affect SSI payment amounts without our behavioral framing;

2. Social Information Intervention — - a group that was sent a form letter identical to that of the "Basic Intervention" group but included additional information on the overall reporting behavior of SSI recipients ("Over 200,000 persons who receive SSI report new wages to us each month.");

3. Salience of Penalties Intervention — a group that was sent a form letter identical to that of the "Basic Intervention" group but included additional information on the possible financial penalties that could be incurred if wages are unreported ("If you do not report your wages to us on purpose, we can stop your SSI payments.");

4. Both Interventions — a group that was sent a form letter identical to that of the "Basic Intervention" group but both contained peer information and made salient the potential financial penalties from failure to report ("Over 200,000 persons who receive SSI report new wages to us each month. If you do not report your wages to us on purpose, we can stop your SSI payments."); and

5. Control — a group that was not sent a letter and therefore served as a control condition. 
Recipients in the first four groups received a direct mailing that reminded them to report any information about earnings that might affect SSI payment amounts. As Figure 1 shows, the four experimental mailings were identical to one another except that the latter three included additional language that provided either social information, information increasing the salience of the penalties, or both. All letters were mailed out on April 15, 2015 to the recipients within the experimental sample. Balance tests were implemented to ensure that the five randomized groups were similar across observable characteristics, including age, years on SSI, gender, reported disability type, race or ethnicity, and state or territory of residence. Table 2 shows that there is no significant effect of being assigned to receive a letter on wage reporting as observed prior to the intervention. ${ }^{18}$

As an additional test of randomization, we use extracts of the SSR data from prior to the intervention and examine whether being assigned to receive a letter has any effect on either the likelihood of reporting earnings or the amount of earnings reported for the months before the intervention. This serves as a useful check of our randomization procedure, since being randomly assigned to receive a letter in April 2015 should have no effect on whether - as of March 2015 - you have reported earning any income during the three months before the intervention (January 2015 to March 2015).

\section{Results}

We are primarily interested in the effect of receiving a reminder letter from the SSA on wage reporting behavior as well as any differential effect by the type of behavioral framing used. In particular, we examine the likelihood that the recipient reported any (countable) earned income and the total amount reported over varying time horizons.

As previously mentioned, there are two features of the data that have important implications for our discussion of the results. First, extracts of the data are created on a monthly basis so that an extract from a particular month provides a snapshot of the SSR data as it exists near the end of that month. Second, SSI recipients are able to report changes in their earnings information both prospectively and retroactively. In other words, every month represents a new opportunity for recipients to update their past or future earnings information in the data. For this reason, whenever we present the effect of the letters on reporting behavior, we must report the results: 1) for a particular extract of the SSR data from a given point in time (e.g., from the July 2015 extract) and 2) for income earned within a particular time horizon (e.g., income earned during the three months post-intervention). Reporting the results in this way will allow us to observe all potential

\footnotetext{
${ }^{18}$ Of the 96 pre-treatment characteristics that we observe, only 9 were determined to be significantly different across treatment and control groups. None of these differences were economically meaningful. Please see Table A.2 in the Appendix for the full balance table.
} 
changes in reported income induced by the letter.

\subsection{Effects on the likelihood of reporting any countable earned income}

Table 3 reports estimates of the effect of receiving the letter on the likelihood of reporting any countable earnings. Each panel represents estimates using a snapshot of the SSR data from a different point in time. Each column is a separate OLS regression, with each pair of columns reporting the estimated effect (without and with controls) of the reminder letters on the likelihood of reporting having earned any income during the time horizon given in the heading of those two columns. The estimate reported for "Constant" gives the baseline likelihood of reporting for the control group of SSI recipients who did not receive any letter, and the estimate reported for the indicator "Received Letter" represents the relative effect of having received any of the four versions of the letter on the likelihood of reporting. Columns 1 and 2 of Panel A show that by the end of April 2015 (approximately two weeks post-mailing), having received a letter is associated with a moderately significant increase in the likelihood of reporting any countable earned income during the months prior to and including the month of intervention. This result implies that receiving the letter induced treated individuals to contact SSA to report earnings from those four months (January 2015 to April 2015). By the end of July 2015 (Panel B), three months post-intervention, the estimated effect increases in both magnitude and significance. Finally, by the end of the calendar year (Panel D), the effect has decayed somewhat and is no longer significant.

Columns 3 and 4 show a similar pattern for the likelihood of reporting earning any countable earned income during the three months post-intervention (May 2015 to July 2015). By three months post-intervention (Panel B), having received a letter is associated with a 0.34 percentage point increase $(\mathrm{p}<0.01)$ in the likelihood of reporting earning any countable income during those three months (May 2015 to July 2015). This represents a 35.1 percent increase in the likelihood of reporting over the mean likelihood of 0.97 percentage points by SSI recipients in the control group. ${ }^{19}$ This effect also decreases in both magnitude and significance by the calendar year end. Looking at how the baseline likelihood of reporting for the control group evolves over time, it appears that the decay in the estimated treatment effect may be in part driven by the control group eventually reporting countable earned income by the end of the calendar year-catching up to the treatment groups - albeit at a delay relative to the SSI recipients who received a letter.

Looking over the full calendar year, Columns 9 and 10 of Panel D report the estimated effect of receiving a letter on the likelihood of reporting earning any income during 2015 by the end of that year. We find that SSI recipients who received a letter were on average 0.33 percentage points $(\mathrm{p}<0.10)$ more likely to have reported any earnings for the year. This represents an 11.1 percent increase in the likelihood of reporting

\footnotetext{
${ }^{19}$ The control group mean is the constant from the regression without controls (Column 3 of Panel B in Table 3).
} 
over the mean likelihood of 3.06 percent by recipients who did not receive a letter. Taken together, these findings suggest that the reminder letters did meaningfully nudge SSI recipients to report changes in their countable earned income. Much of the treatment effect came in the form of reporting countable earnings earlier than they would have otherwise, although some of the effect appears to persist through the year end.

Turning to the specific language of the letters, the bottom row of each panel in Table 3 reports results from F-tests of whether there was a statistically significant effect of which behavioral framing recipients received. The F-tests all have $\mathrm{p}>0.1$, demonstrating that we cannot reject the null that the content of the letters had no effect on whether any countable earnings were reported. While there is clearly an effect of receiving the reminder letter, the specific behavioral framing in the letter does not appear to have mattered. It may be that any notification from SSA is taken very seriously by this population, given their reliance on these benefits, or that the basic information included in all versions of the letter addressed behavioral biases; however, it is not possible to disentangle the reason for no observed differential impacts with the current data. Please see Table A.3 in the Appendix which presents the full results.

\subsection{Effects on the total dollar amount of reported countable earnings}

Table 4 reports estimates for the effect of receiving a letter on the dollar amount of reported countable earnings. Each panel once again uses a snapshot of the SSR data from a different point in time. Each column is a separate OLS regression, with each pair of columns reporting the estimated effect (without and with controls) of the reminder letters on the total amount of income reported during the time horizon given in the heading of the two columns. Reports of no earnings are included in the regressions as zeros. The estimate reported for "Constant" gives the baseline amount of reported earnings for the control group of SSI recipients who did not receive any letter, and the estimate reported for the indicator "Received Letter" represents the estimated relative effect of having received any of the four versions of the letter on the amount of reported earnings.

We find similar patterns of behavior in Table 4 as were reported in Table 3 . There is an initial significant effect of the reminder letters. By July 2015, SSI recipients who received a letter have reported countable income earned during the three months post-intervention (May 2015 to July 2015) that is $\$ 4.89$ higher on average $(\mathrm{p}<0.01)$ than the average reported countable earnings of the control group (which were $\$ 8.88$ during the same time horizon), representing a 55.1 percent increase in the amount of reported earnings. As we observed with the extensive margin results, this immediate effect decreases in both magnitude and significance by the calendar year end. Looking over the full calendar year (Columns 9 and 10 of Panel D), we see no significant difference in the amount of countable earnings reported by whether SSI recipients received a reminder letter. 
However, we do observe statistically significant differences in the total amount of reported countable earnings for the full calendar year as a function of the behaviorally motivated language included in letter. As with Table 3, the bottom row of each panel in Table 4 report results from F-tests of whether we can reject that the content of the letters had no effect on how much countable earnings were reported. In contrast with the findings on the likelihood of reporting any countable earnings, we find somewhat differential effects on the amount of reported countable earnings depending on the behavioral framing in the letter, with F-test p-values that range from 0.04 to 0.5 in Panel D of Table 4. Specifically, as Appendix Table A.4 shows, receiving a letter with both social information and information increasing the salience of the penalties is associated with approximately $\$ 21.27$ higher reported countable earnings over the entire year relative the baseline amount of reported countable earnings for the group that did not receive a letter. ${ }^{20}$

\subsection{Labor supply effects}

Our discussion thus far has interpreted the results as evidence of treatment effects on wage reporting behavior rather than evidence of changes in the true earnings of SSI recipients. While this assumption is likely reasonable given the nature of the behavioral nudges we study, we are also able to directly validate it by examining whether the reminder letters had any effect on labor supply. To do so, we use administrative data on annual (calendar year) earnings from the SSA Master Earnings File (MEF) after the conclusion of 2015. The MEF provides summary and detailed earnings data as reported on individuals' Form W-2 or 1040 Schedule SE forms (if the recipient is self-employed). Because these data are originally sourced from IRS earnings records that are independent of self-reported earnings by SSI recipients, they allow us to distinguish changes in reporting behavior from changes in actual earnings. Using this data, we find no significant effect of receiving any of the letters on the likelihood of having been employed, the dollar amount of W2 earnings reported, or the number of employers in the 2015 calendar year (see Appendix Table A.5). These findings confirm that the results described above reflect changes in reporting behavior and not increases in overall earnings or employment.

\subsection{Cost-effectiveness analysis}

We assess the effectiveness of these reminder letters by comparing the costs associated with the letters with the costs that the SSA would have otherwise incurred for SSI recipients who failed to report their earnings in an accurate and timely manner. That is, the counterfactual we consider when evaluating the effectiveness of the reminder letters is the absence of any intervention (i.e., the way the SSA traditionally identifies and

${ }^{20}$ This estimate is constructed by adding the four individual coefficients reported in Column 10 of Panel D of Appendix Table A.4. 
recovers overpayments; see Benartzi et al. 2017). Given that we find no differential effects by behavioral framing on the extensive margin, we focus our assessment on the effectiveness of the reminder letters in aggregate.

The cost per recipient for each mailing includes $\$ 0.135$ in printing costs and $\$ 0.435$ in postage costs for a total cost of $\$ 0.57$ per recipient, or $\$ 22,800$ for the costs of developing and mailing the letters for the 40,000 individuals (i.e., the implementation cost). We evaluate the cost-effectiveness of this intervention by calculating our most conservative estimate of the benefits. To do this, we focus only on statistically significant increases in aggregate income reported as of July 2015 for the months prior to and including the month intervention as well as the three months post-intervention. By focusing only on this period, we make the conservative assumption that the intervention had no positive differential effect on reported income beyond the first three months.

As of July 2015, our estimates imply that the intervention led SSI recipients who received a letter to report an additional $\$ 10.76$ in countable earned income. Of this increase, an estimated $\$ 5.87$ ( $\mathrm{p}<0.01$; Column 2 of Panel B in Table 4) was for income earned during the three months leading up to and including the month of the intervention and $\$ 4.89$ ( $\mathrm{p}<0.01$; Column 4 of Panel B in Table 4) was for income earned during the 3 months after. The $\$ 5.87$ increase in income earned during the three months prior to the intervention represents a retrospective increase in reported earnings that were not likely reported in time to avoid overpayment of SSI benefits. If we conservatively assume that all unreported earnings are eventually discovered by the SSA, then our intervention merely accelerated the discovery of the overpayments and so may not have generated meaningful savings. However, the additional $\$ 4.89$ in income reported during the three months post-intervention led to a contemporaneous reduction in payments. Even if the earnings were later discovered by the SSA, the SSA would likely have recovered only part of these funds. A recent report by the SSA estimates that about 69 percent of overpayments are never recovered (Social Security Administration 2019). Thus, by shifting the reporting of this income to occur as it was earned, our intervention saved the SSA roughly $\$ 3.37$ (\$4.89 times 0.69 ) per recipient. Given the total cost of $\$ 0.57$ per recipient to print and mail the letters, our highly conservative estimate suggests that the letters generated approximately $\$ 5.91$ in savings on average per $\$ 1$ spent by the SSA $(\$ 3.37 / \$ 0.57)$.

This estimate is quite conservative and almost certainly underestimates the actual savings associated with the reminder letters. For one, it assumes that any increase in reported earnings induced by the intervention would have eventually been discovered by the SSA; if any of these reported earnings would not have been discovered, then the letters would have saved the SSA even more in overpayments. It also assumes that the differential treatment effect for individuals who were nudged into reporting their earnings disappeared fully after July 2015 - three months after the intervention - even though the effects of receiving a letter clearly 
persist beyond this three-month window. Furthermore, the estimates above conservatively assume that, once an overpayment has been made, when earnings are discovered does not matter. However, the SSA has a higher recovery rate when earnings are discovered earlier, suggesting benefits from the $\$ 5.87$ in countable earnings reported in the months before the intervention. These calculations also do not account for the costs associated with a scheduled redetermination that might be avoided due to these reports (approximately $\$ 200$ on average; see Social Security Administration 2015). Taken together, our rough calculations suggest that in addition to having a meaningful impact on wage reporting behavior among SSI recipients, the reminder letters were also cost-effective as a behaviorally informed policy tool.

One caveat to our assessment is that it is not a full social welfare evaluation of the reminder letters. We do not consider any positive or negative utility associated with being nudged to report earnings or directly imposed by the nudge itself (see Allcott and Kessler 2019; Butera et al. 2019). For instance, an SSI recipient reminded of their responsibility to report may feel relieved to have avoided or minimized potential overpayment or may feel anxious from realizing a failure to report past earnings. We also do not account for any potential indirect costs that may have resulted from increases in the use of or reliance on other sources of support, including other welfare programs, or from any increased burden on the agency. Rather, we focus our attention on a comparison of the direct pecuniary costs and benefits associated with sending the reminder letters and the direct pecuniary costs associated with the standard process for recovering overpayments.

\section{Conclusion}

There is a growing interest among policymakers and academics in leveraging insights from psychology and behavioral economics to design nudges to encourage positive behavior, particularly in settings where traditional policy tools have not been fully effective. We examine the results of a large-scale, randomized field experiment designed and implemented by the SSA. The experiment was aimed at encouraging the more accurate and timely reporting of changes in wages for the SSI program, the largest means-tested cash assistance program in the United States. The experimental sample included 50,000 individuals from a group of over 240,000 SSI recipients who met the inclusion criteria for the study, which targeted recipients without earnings who were likely to have a change in earnings. Within this sample, recipients were randomly assigned to a control group $(n=10,000)$ and four separate treatment groups ( $n=10,000$ per group), each of which received a different reminder letter. The results of our study add to an important empirical literature highlighting the potential of such interventions to improve outcomes in policy settings (Hallsworth et al. 2015; 2017).

We find that receiving a letter, regardless of whether behaviorally-motivated language was included, significantly increased the likelihood of reporting any countable earnings and the amount of earnings reported 
in the three months immediately following the intervention. This effect decays slightly over time, decreasing in both significance and magnitude by the year end, though it remains significant on the extensive margin.

Our research design does not allow us to develop rigorous evidence on several important operational considerations. For example, our research design does not allow us to estimate whether the notice might have a larger impact if it is delivered at a different time during the calendar year. In addition, our research design does not allow us to estimate whether sending out the notice on a frequent basis might also improve wage reporting and, if so, the timing of the additional notice relative to the previous notice to maximize the return on investment. Finally, while our research design provides rigorous results for our defined target population, our estimate of the return on investment indicates that it might be worthwhile to test an informational notice to a much broader group of SSI recipients.

More generally, our approach of using a field experiment with granular individual data to test behavioral interventions in policy making is in concordance with the recommendations of the recent U.S. Foundations for Evidence-Based Policymaking Act of 2018 (Hahn 2019). ${ }^{21}$ We hope that more behaviorally-informed interventions and policies at both the federal and state levels are tested and optimized using natural field experiments.

${ }^{21}$ See http://www.congress.gov/bill/115th-congress/house-bill/4174 for details on the bill. 


\section{References}

Allcott, Hunt, "Social Norms and Energy Conservation," Journal of Public Economics, 2011, 95 (9-10), $1082-1095$.

_ and Judd B. Kessler, "The Welfare Effects of Nudges: A Case Study of Energy Use Social Comparisons," American Economic Journal: Applied Economics, 2019, 11 (1), 236-276.

- and Todd Rogers, "The Short-run And Long-run Effects Of Behavioral Interventions: Experimental Evidence From Energy Conservation," American Economic Review, 2014, 104 (10), 3003-3037.

Alm, James, "What Motivates Tax Compliance," Journal of Economic Surveys, 2019, 33 (2), 351-726.

Ben-Shalom, Yonatan and David C. Stapleton, "Long-term Work Activity And Use Of Employment Supports Among New Supplemental Security Income Recipients," Social Security Bulletin, 2015, 75 (1), 73-95.

Benartzi, Shlomo, John Beshears, Katherine L. Milkman, Cass R. Sunstein, Richard H. Thaler, Maya Shankar, Will Tucker-Ray, William J. Congdon, and Steven Galing, "Should Governments Invest More In Nudging?," Psychological Science, 2017, 28 (8), 1041-1055.

Bhargava, Saurabh and Dayanand Manoli, "Psychological Frictions And The Incomplete Take-up Of Social Benefits: Evidence From An IRS Field Experiment," American Economic Review, 2015, 105 (11), $3489-3529$.

Brandon, Alec, John A. List, Robert D. Metcalfe, Michael K. Price, and Florian Rundhammer, "Testing For Crowd Out In Social Nudges: Evidence From A Natural Field Experiment In The Market For Electricity," Proceedings of the National Academy of Sciences, 2019, 116 (12), 5293-5298.

_, Paul J. Ferraro, John A. List, Robert D. Metcalfe, Michael K. Price, and Florian Rundhammer, "Do The Effects of Social Nudges Persist? Theory and Evidence from 38 Natural Field Experiments," 2017. NBER Working Paper, No. 23277.

Busso, Matias, Julian Cristia, and Sarah Humpage, "Did You Get Your Shots? Experimental Evidence On The Role Of Reminders," Journal of Health Economics, 2015, 44, 226-237.

Butera, Luigi, Robert D. Metcalfe, William Morrison, and Dmitry Taubinsky, "The Deadweight Loss Of Social Recognition," 2019. NBER Working Paper, No. 25637. 
Chetty, Raj, "Behavioral Economics And Public Policy: A Pragmatic Perspective," American Economic Review: Papers 83 Proceedings, 2015, 105 (5), 1-33.

_ , Adam Looney, and Kory Kroft, "Salience and Taxation: Theory and Evidence," American Economic Review, 2009, 99 (4), 1145-1177.

- and Emmanuel Saez, "Teaching The Tax Code: Earnings Responses To An Experiment With EITC Recipients," American Economic Journal: Applied Economics, 2013, 5 (1), 1-31.

_ , John Friedman, and Emmanuel Saez, "Using Differences In Knowledge Across Neighborhoods To Uncover The Impacts Of The EITC On Earnings," American Economic Review, 2013, 103 (7), 2683-2721.

Chirico, Michael, Robert Inman, Charles Loeffler, John MacDonald, and Holger Sieg, "Deterring Tax Delinquency In Philadelphia: An Experimental Evaluation Of Nudge Strategies," National Tax Journal, 2019, 72 (3), 479-506.

Choukhmane, Taha, "Default Options And Retirement Saving Dynamics," 2019. Working Paper.

Cialdini, Robert B., "Crafting Normative Messages To Protect The Environment," Current Directions in Psychological Science, 2003, 12 (4), 105-109.

_, Raymond R. Reno, and Carl A. Kallgren, "A Focus Theory Of Normative Conduct: Recycling The Concept Of Norms To Reduce Littering In Public Places," Journal of Personality and Social Psychology, 1990, $58(6), 1015-1026$.

Coffman, Lucas C., Clayton R. Featherstone, and Judd B. Kessler, "Can Social Information Affect What Job You Choose And Keep?," American Economic Journal: Applied Economics, 2017, 9 (1), 96-117.

Congressional Budget Office, "Federal Spending For Means-tested Programs, 2007 to 2027," 2017. CBO Publication No. 52405, Washington, D.C. Retrieved from https://www.cbo.gov/sites/default/ files/115thcongress-2017-2018/reports/52405-means-tested-programs.pdf .

Damgaard, Mette T. and Christina Gravert, "The Hidden Costs Of Nudging: Experimental Evidence From Reminders In Fundraising," Journal of Public Economics, 2018, 157, 15-26.

Deshpande, Manasi, "Does Welfare Inhibit Success? The Long-term Effects Of Removing Low-income Youth From The Disability Rolls," American Economic Review, 2016, 106 (11), 3300-3330.

_, Tal Gross, and Yalun Su, "Disability And Distress: The Effect Of Disability Programs On Financial Outcomes," 2019. NBER Working Paper, No. 25642. 
Dolan, Paul and Robert D. Metcalfe, "Neighbors, Knowledge And Nuggets: Two Natural Field Experiments On The Role Of Incentives On Energy Conservation," 2015. Becker Friedman Institute for Research in Economics Working Paper, No. 2589269.

Dwenger, Nadja, Henrik Kleven, Imran Rasul, and Johannes Rincke, "Extrinsic And Intrinsic Motivations For Tax Compliance: Evidence From A Field Experiment In Germany," American Economic Journal: Applied Economics, 2016, 8 (3), 203-232.

Finkelstein, Amy, "E-Z TAX: Tax Salience and Tax Rates," Quarterly Journal of Economics, 2009, 124 (3), 969-1010.

- and Matthew J. Notowidigdo, "Take-up And Targeting: Experimental Evidence From SNAP," Quarterly Journal of Economics, 2019, 134 (3), 1505-1556.

Frey, Bruno S. and Stephan Meier, "Social Comparisons And Pro-social Behavior: Testing "Conditional Cooperation" In A Field Experiment," American Economic Review, 2004, 94 (5), 1717-1722.

Frey, Erin and Todd Rogers, "Persistence: How Treatment Effects Persist After Interventions Stop," Policy Insights from the Behavioral and Brain Sciences, 2014, 1 (1), 172-179.

Gerber, Alan S., Donald P. Green, and Christopher W. Larimer, "Social Pressure And Voter Turnout: Evidence From A Large-scale Field Experiment," American Political Science Review, 2008, 102 (1), 33-48.

Gneezy, Uri, Stephan Meier, and Pedro Rey-Biel, "When And Why Incentives (Don't) Work To Modify Behavior," Journal of Economic Perspectives, 2011, 25 (4), 191-210.

Goldstein, Noah J., Robert B. Cialdini, and Vladas Griskevicius, "A Room With A Viewpoint: Using Social Norms To Motivate Environmental Conservation In Hotels," Journal of Consumer Research, 2008, $35(3), 472-482$.

Hahn, Robert, "Building Upon Foundations For Evidence-based Policy," Science, 2019, 364 (6440), 534535.

Hallsworth, Michael, John A. List, Robert D. Metcalfe, and Ivo Vlaev, "The Making Of Homo Honoratus: From Omission To Commission,” 2015. NBER Working Paper, No. 21210.

_, _, , and _, "The Behavioralist As Tax Collector: Using Natural Field Experiments To Enhance Tax Compliance," Journal of Public Economics, 2017, 148, 14-31. 
Karlan, Dean, Margaret McConnell, Sendhil Mullainathan, and Jonathan Zinman, "Getting To The Top Of Mind: How Reminders Increase Saving," Management Science, 2016, 62 (12), 3393-3411.

_, Melanie Morten, and Jonathan Zinman, "A Personal Touch In Text Messaging Can Improve Microloan Repayment," Behavioral Science and Policy, 2016, 1 (2), 25-31.

Kaushal, Neeraj, "Elderly Immigrants' Labor Supply Response to Supplemental Security Income," Journal of Policy Analysis and Management, 2010, 29 (1), 137-162.

Liebman, Jeffrey B. and Erzo F. P. Luttmer, "Would People Behave Differently If They Better Understood Social Security? Evidence From A Field Experiment," American Economic Journal: Applied Economics, 2015, 7 (1), 275-299.

List, John A., Robert D. Metcalfe, Michael K. Price, and Florian Rundhammer, "Harnessing Policy Complementarities To Conserve Energy: Evidence From A Natural Field Experiment," 2017. NBER Working Paper, No. 23355.

Luttmer, Erzo F. P. and Monica Singhal, "Tax Morale," Journal of Economic Perspectives, 2014, 28 (4), 149-168.

Milkman, Katherine L., John Beshears, James J. Choice, David Laibson, and Brigitte C. Madrian, "Using Implementation Intentions Prompts To Enhance Influenza Vaccination Rates," Proceedings of the National Academy of Sciences, 2011, 108 (26), 10415-10420.

Neumark, David and Elizabeth Powers, "Welfare for the Elderly: the Effects of SSI on Preretirement Labor Supply," Journal of Public Economics, 2000, 78 (1-2), 51-80.

Perez-Truglia, Ricardo and Ugo Troiano, "Shaming Tax Delinquents," Journal of Public Economics, $2018,167,120-137$.

Rogers, Todd and Erin Frey, "Changing Behavior Beyond The Here And Now," in Gideon Keren and George Wu, eds., Blackwell Handbook of Judgement and Decision Making, Chichester, UK: John Wiley \& Sons, 2015, pp. 725-748.

Slemrod, Joel, "Tax Compliance and Enforcement," Journal of Economic Literature, 2019, 57 (4), 904-954.

Social Security Administration, "Report On Supplemental Security Income Non-medical Redeterminations, Fiscal Year 2011,” 2015. Washington, D.C. Retrieved from https://www.ssa.gov/ legislation/ACOSS_Signed_Senate_Biden_FY2011\%20Redetermination\%20Report\%20-\%20121715.pdf . 
-, "Agency Financial Report, Fiscal Year 2016," 2016. Washington, D.C. Retrieved from https://www.ssa.gov/finance/2016/Full\%20FY\%202016\%20AFR.pdf.

_ , "SSI Annual Statistical Report, 2015," 2017. SSA Publication No. 13-11827, Washington, D.C. Retrieved from https://www.ssa.gov/policy/docs/statcomps/ssi_asr/2015/ssi_asr15.pdf.

_, "Agency Annual Overpayment Waivers Report, Fiscal Year 2019," 2019. Retrieved from https://www.ssa.gov/legislation/Agency\%20Annual\%20Overpayment\%20Waivers\%20Report\%202019.pdf.

Thaler, Richard H. and Cass R. Sunstein, Nudge: Improving Decisions About Health, Wealth And Happiness, Yale University Press, 2008. 

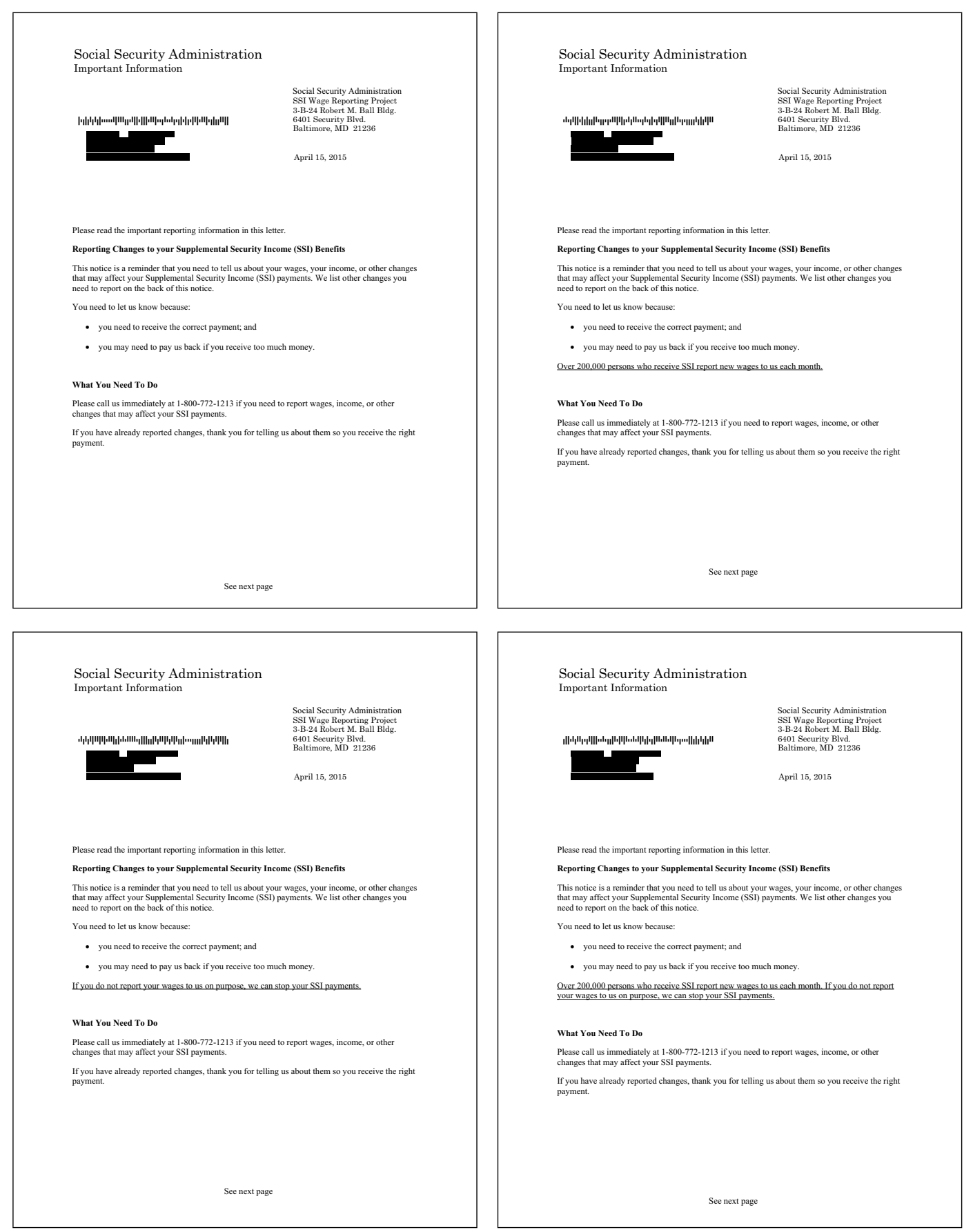

NoTE. - This figure shows the basic intervention mailing with no behavioral framing (top left), the social information intervention mailing (top right), the salience of penalties intervention mailing (bottom left) and the mailing with both social information and salience of penalties language (bottom right) used in the experiment. Additional information on reporting responsibilities appeared on the back of the mailing and was identical across the four mailings.

FIG. 1.-Sample Form Letter Mailings 
TABLE 1

Summary Statistics

(1)

Universe of

Working Age

SSI Recipients
(2)

Experimental

Sample

\begin{tabular}{|c|c|c|}
\hline \multicolumn{3}{|l|}{ Panel A. Overall } \\
\hline Reported Any Countable Earnings in the Past Year & 2.54 & 0.00 \\
\hline Amount of Countable Earnings Reported $(\$)$ & 4.67 & 0.00 \\
\hline Time on SSI Program (Years) & 12.53 & 2.97 \\
\hline \multicolumn{3}{|c|}{ Panel B. Demographic Information } \\
\hline Age & 51.58 & 35.91 \\
\hline \multicolumn{3}{|l|}{ Race } \\
\hline Asian & 2.63 & 0.64 \\
\hline Black & 22.86 & 17.62 \\
\hline Hispanic & 9.01 & 4.38 \\
\hline Native American or Alaskan Native & 0.87 & 0.62 \\
\hline Other/Unknown & 25.62 & 43.89 \\
\hline White & 39.01 & 32.86 \\
\hline Female & 56.62 & 52.13 \\
\hline Has English As A Primary Language & 82.58 & 100.00 \\
\hline \multicolumn{3}{|c|}{ Panel C. Disability Information } \\
\hline Has a Permanent Disability & 33.18 & 10.62 \\
\hline \multicolumn{3}{|l|}{ Medical Diary Type } \\
\hline Medical Improvement Expected (MIE) & 2.46 & 6.62 \\
\hline Medical Improvement Possible (MIP) & 64.36 & 82.77 \\
\hline Medical Improvement Not Expected (MINE) & 33.18 & 10.62 \\
\hline Observations & $5,056,608$ & 50,000 \\
\hline \multicolumn{3}{|c|}{$\begin{array}{l}\text { NoтE.-This table provides summary statistics for the universe of SSI adult (age 18-64) recipients receiving } \\
\text { benefits for a disability or blindness who were in current pay status in March } 2015 \text { (column 1) and the sub- } \\
\text { set of recipients in our experimental sample (column 2) based on data from the SSA Supplemental Security } \\
\text { Record. Panel A reports overview statistics, Panel B reports basic demographic information, and Panel C re- } \\
\text { ports details on disability status and medical diary type across each sample. All table entries represent group } \\
\text { means. The count of individuals in each group is listed in the final row. }\end{array}$} \\
\hline
\end{tabular}


TABLE 2

RANDOMization CHECK

\begin{tabular}{lccccc}
\hline & \multicolumn{2}{c}{ Reported Any Earnings } & & \multicolumn{2}{c}{ Amount of Earnings Reported } \\
\cline { 2 - 3 } \cline { 5 - 6 } & $(1)$ & $(2)$ & & $(3)$ & $(4)$ \\
\hline Received Letter & 0.0008 & 0.0008 & & 0.3112 & 0.2921 \\
& $(0.0006)$ & $(0.0006)$ & & $(0.2960)$ & $(0.2958)$ \\
Constant & $0.0020^{* * *}$ & -0.0013 & & $0.7895^{* * *}$ & -1.1022 \\
& $(0.0005)$ & $(0.0022)$ & & $(0.2648)$ & $(1.1406)$ \\
\hline R-squared & 0.000 & 0.005 & & 0.000 & 0.005 \\
Prob $>$ F & 0.363 & 0.368 & & 0.107 & 0.106 \\
\hline Controls & & Yes & & & Yes \\
Observations & 50,000 & 50,000 & & 50,000 & 50,000 \\
\hline
\end{tabular}

NotE. - This table reports estimates of the aggregate effect of receiving a letter reminding SSI recipients of their wage reporting responsibilities on the likelihood of reporting any countable earnings and the dollar amount of countable earnings reported. Each column presents a separate regression. Columns 1 and 2 report estimates where the dependent variable is an indicator for whether the recipient reported any countable earnings. Columns 3 and 4 report estimates where the dependent variable is the amount of countable earnings reported by the recipient. The time horizon for the dependent variable in each column is the three months prior to the treatment letters being mailed (January 2015 - March 2015). Each dependent variable is based on a three-month measure of countable earnings created using monthly extracts of the SSR data for January, February, and March 2015. Controls include age, gender, dummies for race/ethnicity, state or territory of residence, years on the SSI program, an indicator for whether the recipient is permanently disabled, and indicators for the primary disability diagnosis. Coefficients are reported for a "Received Letter" indicator denoting whether the recipient received a letter (experimental mailing) from the SSA. The table also reports p-values from an F-test of whether there is no differential effect of the behavioral framing. Significance levels $10 \%, 5 \%$, and $1 \%$ are denoted by $*$, ${ }^{*}$, and $* * *$, respectively 
TABLE 3

Reported Any Countable Earnings

\begin{tabular}{|c|c|c|c|c|c|c|c|c|c|c|}
\hline & \multicolumn{2}{|c|}{ Jan to Apr 2015} & \multicolumn{2}{|c|}{ May to Jul 2015} & \multicolumn{2}{|c|}{ May to Oct 2015} & \multicolumn{2}{|c|}{ May to Dec 2015} & \multicolumn{2}{|c|}{ Jan to Dec 2015} \\
\hline & $(1)$ & $(2)$ & $(3)$ & $(4)$ & $(5)$ & $(6)$ & (7) & $(8)$ & (9) & $(10)$ \\
\hline \multicolumn{11}{|c|}{ Panel A. SSR Monthly Extract from April 2015} \\
\hline Received Letter & $\begin{array}{c}0.0016^{* *} \\
(0.0008)\end{array}$ & $\begin{array}{c}0.0016^{*} \\
(0.0008)\end{array}$ & & & & & & & & \\
\hline Constant & $\begin{array}{l}0.0041^{* * *} \\
(0.0007)\end{array}$ & $\begin{array}{c}-0.0073^{* *} \\
(0.0032)\end{array}$ & & & & & & & & \\
\hline R-squared & 0.000 & 0.006 & & & & & & & & \\
\hline Prob $>$ F & 0.615 & 0.592 & & & & & & & & \\
\hline \multicolumn{11}{|c|}{ Panel B. SSR Monthly Extract from July 2015} \\
\hline Received Letter & $\begin{array}{l}0.0035^{* * *} \\
(0.0012)\end{array}$ & $\begin{array}{c}0.0036^{* * *} \\
(0.0012)\end{array}$ & $\begin{array}{l}0.0033^{* * *} \\
(0.0012)\end{array}$ & $\begin{array}{c}0.0034^{* * *} \\
(0.0012)\end{array}$ & & & & & & \\
\hline Constant & $\begin{array}{l}0.0087^{* * *} \\
(0.0011)\end{array}$ & $\begin{array}{c}-0.0110^{* *} \\
(0.0046)\end{array}$ & $\begin{array}{l}0.0097^{* * *} \\
(0.0011)\end{array}$ & $\begin{array}{c}-0.0079^{*} \\
(0.0048)\end{array}$ & & & & & & \\
\hline R-squared & 0.000 & 0.009 & 0.000 & 0.009 & & & & & & \\
\hline Prob $>$ F & 0.930 & 0.904 & 0.916 & 0.905 & & & & & & \\
\hline \multicolumn{11}{|c|}{ Panel C. SSR Monthly Extract from October 2015} \\
\hline Received Letter & $\begin{array}{c}0.0017 \\
(0.0014)\end{array}$ & $\begin{array}{c}0.0018 \\
(0.0013)\end{array}$ & $\begin{array}{c}0.0027^{*} \\
(0.0014)\end{array}$ & $\begin{array}{c}0.0028^{*} \\
(0.0014)\end{array}$ & $\begin{array}{c}0.0029^{*} \\
(0.0016)\end{array}$ & $\begin{array}{c}0.0030^{*} \\
(0.0016)\end{array}$ & & & & \\
\hline Constant & $\begin{array}{l}0.0135^{* * *} \\
(0.0012)\end{array}$ & $\begin{array}{c}-0.0091^{*} \\
(0.0052)\end{array}$ & $\begin{array}{l}0.0146^{* * *} \\
(0.0013)\end{array}$ & $\begin{array}{c}-0.0054 \\
(0.0055)\end{array}$ & $\begin{array}{l}0.0185^{* * *} \\
(0.0014)\end{array}$ & $\begin{array}{c}-0.0076 \\
(0.0061)\end{array}$ & & & & \\
\hline R-squared & 0.000 & 0.011 & 0.000 & 0.012 & 0.000 & 0.014 & & & & \\
\hline Prob $>$ F & 0.322 & 0.257 & 0.518 & 0.456 & 0.484 & 0.420 & & & & \\
\hline \multicolumn{11}{|c|}{ Panel D. SSR Monthly Extract from December 2015} \\
\hline Received Letter & $\begin{array}{c}0.0014 \\
(0.0015)\end{array}$ & $\begin{array}{c}0.0015 \\
(0.0015)\end{array}$ & $\begin{array}{c}0.0022 \\
(0.0016)\end{array}$ & $\begin{array}{c}0.0023 \\
(0.0016)\end{array}$ & $\begin{array}{c}0.0023 \\
(0.0018)\end{array}$ & $\begin{array}{c}0.0025 \\
(0.0018)\end{array}$ & $\begin{array}{c}0.0025 \\
(0.0018)\end{array}$ & $\begin{array}{c}0.0027 \\
(0.0018)\end{array}$ & $\begin{array}{c}0.0032 \\
(0.0020)\end{array}$ & $\begin{array}{c}0.0034^{*} \\
(0.0020)\end{array}$ \\
\hline Constant & $\begin{array}{l}0.0173^{* * *} \\
(0.0013)\end{array}$ & $\begin{array}{c}-0.0116^{* *} \\
(0.0058)\end{array}$ & $\begin{array}{l}0.0183^{* * *} \\
(0.0014)\end{array}$ & $\begin{array}{c}-0.0065 \\
(0.0060)\end{array}$ & $\begin{array}{l}0.0245^{* * *} \\
(0.0016)\end{array}$ & $\begin{array}{r}-0.0120^{*} \\
(0.0069)\end{array}$ & $\begin{array}{l}0.0259^{* * *} \\
(0.0016)\end{array}$ & $\begin{array}{c}-0.0102 \\
(0.0071) \\
\end{array}$ & $\begin{array}{l}0.0306^{* * *} \\
(0.0018)\end{array}$ & $\begin{array}{c}-0.0160^{* *} \\
(0.0077)\end{array}$ \\
\hline R-squared & 0.000 & 0.012 & 0.000 & 0.012 & 0.000 & 0.017 & 0.000 & 0.017 & 0.000 & 0.019 \\
\hline Prob $>$ F & 0.230 & 0.178 & 0.513 & 0.442 & 0.297 & 0.245 & 0.498 & 0.435 & 0.275 & 0.216 \\
\hline Controls & & Yes & & Yes & & Yes & & Yes & & Yes \\
\hline Observations & 50,000 & 50,000 & 50,000 & 50,000 & 50,000 & 50,000 & 50,000 & 50,000 & 50,000 & 50,000 \\
\hline $\begin{array}{l}\text { NOTE. - This table } \mathrm{r} \\
\text { ings. Each column p } \\
\text { race/ethnicity, state } \\
\text { horizon for the deper } \\
\text { the treatment letters } \\
\text { treatment (May } 2015 \\
\text { horizon is post treatr } \\
\text { using a different extr } \\
\text { Coefficients are repor } \\
\text { p-values from an F-t }\end{array}$ & $\begin{array}{l}\text { variable vari } \\
\text { nailed (i.e., } \\
\text { 2015); Colu } \\
\text { hrough the y } \\
\text { the SSR as } \\
\text { r a "Receive } \\
\text { whether ther }\end{array}$ & $\begin{array}{l}5 \text { and } 6 \text { rep } \\
\text { end (May } 20\end{array}$ & $\begin{array}{l}1 \text { prograll, } \\
\text { earnings we } \\
\text { imates whe } \\
\text { ima 2015); a }\end{array}$ & 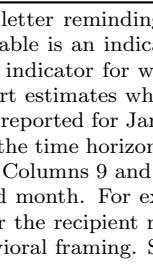 & $\begin{array}{l}\text { he time horiz } \\
\text { ye six month } \\
\text { eport estimat } \\
\text { ole, Panel A } \\
\text { ved a letter } \\
\text { ficance levels }\end{array}$ & $\begin{array}{l}\text { for the deper } \\
015 \text {; C Column } \\
\text { ost treatment } \\
\text { where the tim } \\
\text { orts estimate } \\
\text { perimental ma } \\
\%, 5 \% \text {, and } 1\end{array}$ & $\begin{array}{l}\text { g responsibiliti } \\
\text { i any countable } \\
\text { sabled, and ind } \\
\text { variable is the } \\
\text { nd } 4 \text { report estir } \\
\text { y } 2015-\text { Oct } 20 \\
\text { rizon is the full } \\
\text { ng an extract of } \\
\text { from the SSA. } \\
\text { e denoted by *, }\end{array}$ & $\begin{array}{l}\text { on the likeli } \\
\text { arnings. Con } \\
\text { ators for the } \\
\text { aree months } 1 \\
\text { tes where th } \\
\text { \%); Columns } 7 \\
\text { lendar year f } \\
\text { he SSR data } \\
\text { Che second ro } \\
* \text {, and }{ }^{* * *} \text {, re }\end{array}$ & $\begin{array}{l}\text { of reporting an } \\
\text { include age, ger } \\
\text { ary disability di } \\
\text { to and includins } \\
\text { e horizon is the } \\
8 \text { report estimat } \\
15 \text {. Each panel } \\
\text { existed at the } \\
\text { the bottom of } \\
\text { tively. }\end{array}$ & $\begin{array}{l}\text { countable earn } \\
\text { ler, dummies fo } \\
\text { nosis. The tim } \\
\text { the month wher } \\
\text { ree months pos } \\
\text { s where the tim } \\
\text { esents estimate } \\
\text { d of April } 2015 \\
\text { ch panel report }\end{array}$ \\
\hline
\end{tabular}


TABLE 4

Amount Of Countable Earnings Reported

\begin{tabular}{|c|c|c|c|c|c|c|c|c|c|c|}
\hline & \multicolumn{2}{|c|}{ Jan to Apr 2015} & \multicolumn{2}{|c|}{ May to Jul 2015} & \multicolumn{2}{|c|}{ May to Oct 2015} & \multicolumn{2}{|c|}{ May to Dec 2015} & \multicolumn{2}{|c|}{ Jan to Dec 2015} \\
\hline & (1) & $(2)$ & $(3)$ & $(4)$ & $(5)$ & $(6)$ & $(7)$ & (8) & $(9)$ & $(10)$ \\
\hline \multicolumn{11}{|c|}{ Panel A. SSR Monthly Extract from April 2015} \\
\hline Received Letter & $\begin{array}{c}1.9736^{*} \\
(1.0792)\end{array}$ & $\begin{array}{c}1.9550^{*} \\
(1.0797)\end{array}$ & & & & & & & & \\
\hline Constant & $\begin{array}{l}2.6654^{* * *} \\
(0.9652)\end{array}$ & $\begin{array}{r}-7.2321^{*} \\
(4.1633)\end{array}$ & & & & & & & & \\
\hline R-squared & 0.000 & 0.003 & & & & & & & & \\
\hline Prob $>$ F & 0.278 & 0.285 & & & & & & & & \\
\hline \multicolumn{11}{|c|}{ Panel B. SSR Monthly Extract from July 2015} \\
\hline Received Letter & $\begin{array}{l}5.7075^{* * * *} \\
(1.6645)\end{array}$ & $\begin{array}{l}5.8674^{* * *} \\
(1.6644)\end{array}$ & $\begin{array}{l}4.6924^{* * *} \\
(1.7515)\end{array}$ & $\begin{array}{l}4.8852^{* * * *} \\
(1.7500)\end{array}$ & & & & & & \\
\hline Constant & $\begin{array}{l}5.4218^{* * *} \\
(1.4887)\end{array}$ & $\begin{array}{r}-11.0482^{*} \\
(6.4177)\end{array}$ & $\begin{array}{l}8.8803^{* * * *} \\
(1.5666)\end{array}$ & $\begin{array}{c}-3.4242 \\
(6.7476)\end{array}$ & & & & & & \\
\hline R-squared & 0.000 & 0.004 & 0.000 & 0.006 & & & & & & \\
\hline Prob $>$ F & 0.826 & 0.826 & 0.219 & 0.237 & & & & & & \\
\hline \multicolumn{11}{|c|}{ Panel C. SSR Monthly Extract from October 2015} \\
\hline Received Letter & $\begin{array}{l}4.2045^{* *} \\
(2.0730)\end{array}$ & $\begin{array}{l}4.3783^{* *} \\
(2.0722)\end{array}$ & $\begin{array}{c}2.5463 \\
(2.2868)\end{array}$ & $\begin{array}{c}2.7410 \\
(2.2844)\end{array}$ & $\begin{array}{c}3.3219 \\
(4.4857)\end{array}$ & $\begin{array}{c}3.6771 \\
(4.4789)\end{array}$ & & & & \\
\hline Constant & $\begin{array}{l}10.8549^{* * *} \\
(1.8541)\end{array}$ & $\begin{array}{c}2.1347 \\
(7.9901) \\
\end{array}$ & $\begin{array}{l}15.2602^{* * *} \\
(2.0454)\end{array}$ & $\begin{array}{c}7.0529 \\
(8.8083) \\
\end{array}$ & $\begin{array}{l}34.3017^{* * *} \\
(4.0121) \\
\end{array}$ & $\begin{array}{c}16.4133 \\
(17.2701) \\
\end{array}$ & & & & \\
\hline R-squared & 0.000 & 0.004 & 0.000 & 0.006 & 0.000 & 0.0074 & & & & \\
\hline Prob $>$ F & 0.631 & 0.610 & 0.048 & 0.053 & 0.030 & 0.032 & & & & \\
\hline \multicolumn{11}{|c|}{ Panel D. SSR Monthly Extract from December 2015} \\
\hline Received Letter & $\begin{array}{c}4.0612^{*} \\
(2.2235)\end{array}$ & $\begin{array}{l}4.2021^{*} \\
(2.2221)\end{array}$ & $\begin{array}{l}2.7821 \\
(2.3815)\end{array}$ & $\begin{array}{c}2.9653 \\
(2.3785)\end{array}$ & $\begin{array}{c}3.2694 \\
(4.6433)\end{array}$ & $\begin{array}{c}3.6181 \\
(4.6349)\end{array}$ & $\begin{array}{c}2.7396 \\
(6.1286)\end{array}$ & $\begin{array}{c}3.2123 \\
(6.1160)\end{array}$ & $\begin{array}{c}6.8007 \\
(7.6379)\end{array}$ & $\begin{array}{c}7.4144 \\
(7.6220)\end{array}$ \\
\hline Constant & $\begin{array}{l}13.8605^{* * *} \\
(1.9888)\end{array}$ & $\begin{array}{c}-1.4013 \\
(8.5682)\end{array}$ & $\begin{array}{l}17.3455^{* * * *} \\
(2.1300)\end{array}$ & $\begin{array}{c}5.3151 \\
(9.1711)\end{array}$ & $\begin{array}{l}39.3275^{* * *} \\
(4.1531)\end{array}$ & $\begin{array}{c}12.0838 \\
(17.8715)\end{array}$ & $\begin{array}{l}55.0110^{* * *} \\
(5.4816)\end{array}$ & $\begin{array}{c}16.1305 \\
(23.5822)\end{array}$ & $\begin{array}{l}68.8715^{* * *} \\
(6.8315)\end{array}$ & $\begin{array}{c}14.7291 \\
(29.3894)\end{array}$ \\
\hline $\mathrm{R}$-squared & 0.000 & 0.005 & 0.000 & 0.006 & 0.000 & 0.007 & 0.000 & 0.008 & 0.000 & 0.008 \\
\hline Prob > F & 0.509 & 0.491 & 0.089 & 0.096 & 0.041 & 0.042 & 0.054 & 0.055 & 0.086 & 0.084 \\
\hline Controls & & Yes & & Yes & & Yes & & Yes & & Yes \\
\hline Observations & 50,000 & 50,000 & 50,000 & 50,000 & 50,000 & 50,000 & 50,000 & 50,000 & 50,000 & 50,000 \\
\hline $\begin{array}{l}\text { NOTE.-This table re } \\
\text { Each column presents } \\
\text { or territory of residen } \\
\text { variable varies by col } \\
\text { mailed (i.e., whether } \\
\text {-July 2015); Column } \\
\text { treatment through th } \\
\text { extract of the SSR da } \\
\text { reported for a "Recei } \\
\text { F-test of whether the }\end{array}$ & $\begin{array}{l}\text { ountable } \\
\text { dd } 6 \text { repor } \\
\text { end (May }\end{array}$ & $\begin{array}{l}2 \text { report esti } \\
\text { ims were repor } \\
\text { imates where } \\
\text { - Dec } 2015) \text {; } \\
\text { end of the in } \\
\text { denoting whe } \\
\text { ffet the be }\end{array}$ & $\begin{array}{l}\text { es where tory time } \\
\text { for January } 201 \\
\text { time horizon is } \\
\text { i Columns } 9 \text { and } \\
\text { ated month. For } \\
\text { r the recipient } \\
\text { ioral framing. Si }\end{array}$ & $\begin{array}{l}\text { - April } 2015 \\
\text { he six month } \\
0 \text { report estir } \\
\text { example, Pan }\end{array}$ & $\begin{array}{l}\text { recipients of } t \\
\text { table earnings } \\
\text { tanently disable } \\
\text { ependent varial } \\
\text { lumns } 3 \text { and } 4 \\
t \text { treatment (M } \\
\text { where the tim } \\
\text { eports estimat }\end{array}$ & $\begin{array}{l}\text { eir wage repor } \\
\text { eported by the } \\
1 \text {, and indicatol } \\
\text { is the three } \\
\text { eport estimate } \\
\text { y } 2015 \text { - Oct } \\
\text { horizon is the } \\
\text { using an extr }\end{array}$ & $\begin{array}{l}\text { responsibilities } \\
\text { oient. Controls } \\
\text { the primary di } \\
\text { hs prior to and } \\
\text { here the time ho } \\
\text { ); Columns } 7 \text { a } \\
\text { alendar year for } \\
\text { f the SSR data }\end{array}$ & $\begin{array}{l}\mathrm{n} \text { the dollar a } \\
\text { cclude age, ge } \\
\text { ability diagnos } \\
\text { ncluding the } \\
\text { izon is the th } \\
\text { d } 8 \text { report est } \\
\text { 2015. Each pa } \\
\text { sit existed at }\end{array}$ & $\begin{array}{l}\text { ta of countable } \\
\text { dummies for rac } \\
\text { he time horizon } \\
\text { when the treat } \\
\text { nonths post treat } \\
\text { en where the tim } \\
\text { resents estimates } \\
\text { end of April } 2015\end{array}$ & $\begin{array}{l}\text { arnings report } \\
\text { e/ethnicity, st } \\
\text { or the depend } \\
\text { nent letters w } \\
\text { ment (May 2 } \\
\text { e horizon is p } \\
\text { using a differ } \\
\text { Coefficients } \\
\text { p-values from }\end{array}$ \\
\hline
\end{tabular}




\title{
Nudging Timely Wage Reporting: Field Experimental Evidence from the United States Social Supplementary Income Program
}

\section{ONLINE APPENDiX}

\author{
C. Yiwei Zhang ${ }^{\dagger} \quad$ Jeffrey Hemmeter ${ }^{\ddagger} \quad$ Judd B. Kessler ${ }^{\S}$
}

Robert D. Metcalfe Robert Weathers"

${ }^{\dagger}$ Corresponding Author. University of Wisconsin-Madison, 1300 Linden Drive, Madison, WI 53706, USA, cyzhang@wisc.edu ${ }^{\ddagger}$ Office of Research, Demonstration, and Employment Support, Social Security Administration, 6401 Security Boulevard, Baltimore, MD 21235, USA, jeffrey.hemmeter@ssa.gov

$\S$ Business Economics and Public Policy Department, The Wharton School, University of Pennsylvania, 3733 Spruce Street, Philadelphia, PA 19104, USA, and NBER, judd.kessler@wharton.upenn.edu

『Markets, Public Policy \& Law Department, Questrom School of Business, Boston University, 595 Commonwealth Avenue, Boston, MA, 02215, USA, and NBER, rdmet@bu.edu

"Office of Retirement and Disability Policy, Social Security Administration, 6401 Security Boulevard, Baltimore, MD 21235, USA, robert.weathers@ssa.gov 
APPENDIX TABLE A.1

Additional Summary Statistics

\begin{tabular}{|c|c|c|c|c|c|c|c|c|c|c|c|}
\hline & \multicolumn{11}{|c|}{ Panel A. State or Territory of Residence } \\
\hline & $\begin{array}{l}\text { Universe of } \\
\text { Recipients }\end{array}$ & \multicolumn{2}{|l|}{$\begin{array}{c}\text { Experimental } \\
\text { Sample }\end{array}$} & $\begin{array}{l}\text { Universe of } \\
\text { Recipients }\end{array}$ & \multicolumn{2}{|l|}{$\begin{array}{c}\text { Experimental } \\
\text { Sample }\end{array}$} & \multirow{2}{*}{$\begin{array}{c}\text { Universe of } \\
\text { Recipients }\end{array}$} & \multicolumn{2}{|l|}{$\begin{array}{c}\text { Experimental } \\
\text { Sample }\end{array}$} & $\begin{array}{l}\text { Universe of } \\
\text { Recipients }\end{array}$ & $\begin{array}{c}\text { Experimental } \\
\text { Sample }\end{array}$ \\
\hline AK & 2.31 & 3.15 & ID & 3.44 & 3.55 & $\mathrm{MT}$ & & 0.25 & $\mathrm{RI}$ & 0.44 & 0.41 \\
\hline $\mathrm{AL}$ & 0.17 & 0.11 & IL & 1.67 & 2.55 & $\mathrm{NC}$ & 0.37 & 0.55 & $\mathrm{SC}$ & 1.52 & 1.80 \\
\hline $\mathrm{AR}$ & 1.40 & 0.37 & IN & 0.66 & 0.80 & ND & 0.49 & 0.11 & SD & 0.18 & 0.19 \\
\hline $\mathrm{AZ}$ & 1.27 & 1.99 & $\mathrm{KS}$ & 0.62 & 0.93 & $\mathrm{NE}$ & 0.28 & 0.64 & $\mathrm{TN}$ & 2.51 & 3.10 \\
\hline $\mathrm{CA}$ & 14.08 & 1.47 & KY & 2.51 & 2.72 & $\mathrm{NH}$ & 2.10 & 1.69 & $\mathrm{TX}$ & 6.86 & 9.25 \\
\hline $\mathrm{CO}$ & 0.94 & 1.06 & LA & 2.22 & 3.07 & NJ & 0.79 & 0.89 & UT & 0.39 & 0.42 \\
\hline $\mathrm{CT}$ & 0.84 & 0.78 & MA & 0.55 & 0.69 & NM & 7.70 & 5.19 & VA & 0.23 & 0.26 \\
\hline $\mathrm{DC}$ & 0.20 & 0.23 & MD & 1.46 & 1.67 & NV & 2.91 & 3.77 & $\mathrm{VT}$ & 1.92 & 2.36 \\
\hline $\mathrm{DE}$ & 0.36 & 0.40 & $\mathrm{ME}$ & 2.48 & 2.76 & NY & 0.11 & 0.11 & WA & 2.02 & 2.51 \\
\hline FL & 5.52 & 5.99 & MI & 3.70 & 4.60 & $\mathrm{OH}$ & 4.26 & 5.54 & WI & 1.14 & 1.15 \\
\hline GA & 3.14 & 3.92 & $\mathrm{MN}$ & 1.20 & 1.32 & OK & 1.25 & 1.77 & WV & 1.48 & 1.83 \\
\hline HI & 0.32 & 0.05 & MO & 1.56 & 1.90 & OR & 1.12 & 1.31 & WY & 0.09 & 0.13 \\
\hline IA & 0.39 & 0.47 & MS & 1.92 & 3.03 & PA & 4.69 & 5.15 & NMI & 0.01 & \\
\hline \multicolumn{12}{|c|}{ Panel B. Primary Disability Diagnosis } \\
\hline & & & & $\begin{array}{l}\text { Universe of } \\
\text { Recipients }\end{array}$ & $\begin{array}{c}\text { Experimental } \\
\text { Sample }\end{array}$ & & & & & $\begin{array}{l}\text { Universe of } \\
\text { Recipients }\end{array}$ & $\begin{array}{c}\text { Experimental } \\
\text { Sample }\end{array}$ \\
\hline \multicolumn{4}{|c|}{ Infectious and Parasitic } & 1.32 & 1.77 & \multicolumn{4}{|c|}{ Circulatory System } & 5.66 & 4.29 \\
\hline \multicolumn{4}{|c|}{ Neoplasms } & 1.39 & 2.50 & \multicolumn{4}{|c|}{ Respiratory System } & 2.41 & 2.07 \\
\hline \multicolumn{4}{|c|}{ Endocrine } & 3.08 & 2.95 & \multicolumn{4}{|c|}{ Digestive System } & 1.06 & 1.89 \\
\hline \multicolumn{4}{|c|}{ Blood } & 0.28 & 0.77 & \multicolumn{4}{|c|}{ Genitourinary System } & 1.03 & 2.83 \\
\hline \multicolumn{4}{|c|}{ Autistic Disorders } & 1.19 & 1.18 & \multicolumn{4}{|c|}{ Skin } & 0.18 & 0.50 \\
\hline \multicolumn{4}{|c|}{ Developmental disorders } & 0.29 & 0.43 & \multicolumn{4}{|c|}{ Musculoskeletal } & 16.57 & 12.71 \\
\hline \multicolumn{4}{|c|}{ Childhood and adolescent disorders N.E.C. ${ }^{\dagger}$} & 0.22 & 0.48 & \multicolumn{4}{|c|}{ Congenital Anomalies } & 0.53 & 0.52 \\
\hline \multicolumn{4}{|c|}{ Intellectual disability } & 13.26 & 6.19 & \multicolumn{4}{|c|}{ Injuries } & 2.73 & 3.66 \\
\hline \multicolumn{4}{|c|}{ Mood disorders } & 16.32 & 21.64 & \multicolumn{4}{|c|}{ Other } & 0.17 & 0.21 \\
\hline \multicolumn{4}{|c|}{ Organic Mental Disorders } & 3.57 & 2.94 & \multicolumn{4}{|c|}{ Unknown } & 7.85 & 2.26 \\
\hline Schi & phrenia & & & 5.35 & 8.88 & Deaf & & & & 0.68 & 0.66 \\
\hline Oth & Mental disor & & & 8.74 & 9.10 & Blinc & & & & 1.08 & 1.23 \\
\hline Ner & us System & & & 5.05 & 8.35 & & & & & & \\
\hline
\end{tabular}

NOTE.- This table provides summary statistics on the state or territory of residence (Panel A) and the primary disability diagnosis (Panel B) for the universe of SSI recipients receiving benefits for a disability who were in current pay status in March $2015(\mathrm{~N}=5,056,608)$ and the subset of recipients in our experimental sample $(\mathrm{N}=50,000)$.

${ }^{\dagger}$ N.E.C. $=$ Not Elsewhere Classified. 
APPENDIX TABLE A.2

Balance Checks

\begin{tabular}{|c|c|c|c|c|c|c|c|}
\hline & $\begin{array}{c}\text { (1) } \\
\text { Full } \\
\text { Sample }\end{array}$ & $\begin{array}{c}(2) \\
\text { Social } \\
\text { Framing }\end{array}$ & $\begin{array}{c}(3) \\
\text { Penalty } \\
\text { Framing }\end{array}$ & $\begin{array}{c}\text { (4) } \\
\text { Both } \\
\text { Framings }\end{array}$ & $\begin{array}{c}(5) \\
\text { No } \\
\text { Framing }\end{array}$ & $\begin{array}{c}(6) \\
\text { Control } \\
\text { (No Letter) }\end{array}$ & $\begin{array}{c}(7) \\
\text { F-test } \\
\text { p-value }\end{array}$ \\
\hline \multicolumn{8}{|c|}{ Panel A. Overall } \\
\hline Redetermination Score Rank & $\begin{array}{c}335,250 \\
(198,947)\end{array}$ & $\begin{array}{c}336,717 \\
(199,839)\end{array}$ & $\begin{array}{c}335,043 \\
(199,008)\end{array}$ & $\begin{array}{c}334,291 \\
(197,854)\end{array}$ & $\begin{array}{c}334,837 \\
(199,619)\end{array}$ & $\begin{array}{c}335,362 \\
(198,439)\end{array}$ & 0.93 \\
\hline \multicolumn{8}{|l|}{ In the 6 months pre-mailing: } \\
\hline Any countable earnings & 0.01 & 0.01 & 0.01 & 0.01 & 0.01 & 0.00 & 0.07 \\
\hline Amount of countable earnings reported $(\$)$ & $\begin{array}{c}3.28 \\
(58.59)\end{array}$ & $\begin{array}{c}3.00 \\
(48.51)\end{array}$ & $\begin{array}{c}4.76 \\
(75.36)\end{array}$ & $\begin{array}{c}2.49 \\
(50.99)\end{array}$ & $\begin{array}{c}3.30 \\
(50.62)\end{array}$ & $\begin{array}{c}2.86 \\
(62.98)\end{array}$ & 0.06 \\
\hline \multicolumn{8}{|l|}{ In the 3 months pre-mailing: } \\
\hline Any countable earnings & 0.00 & 0.00 & 0.00 & 0.00 & 0.00 & 0.00 & 0.26 \\
\hline Amount of countable earnings reported $(\$)$ & $\begin{array}{c}1.04 \\
(26.48)\end{array}$ & $\begin{array}{c}0.95 \\
(26.35)\end{array}$ & $\begin{array}{c}1.67 \\
(36.50)\end{array}$ & $\begin{array}{c}0.90 \\
(25.30)\end{array}$ & $\begin{array}{c}0.89 \\
(20.55)\end{array}$ & $\begin{array}{c}0.79 \\
(20.40)\end{array}$ & 0.13 \\
\hline \multicolumn{8}{|l|}{ Time on SSI program (years): } \\
\hline Less than 2 years & 0.46 & 0.47 & 0.46 & 0.46 & 0.47 & 0.47 & 0.71 \\
\hline Between 2 to 4 years & 0.38 & 0.38 & 0.38 & 0.38 & 0.37 & 0.38 & 0.42 \\
\hline Between 4 to 6 years & 0.16 & 0.16 & 0.16 & 0.16 & 0.16 & 0.16 & 0.87 \\
\hline \multicolumn{8}{|c|}{ Panel B. Demographic Information } \\
\hline \multicolumn{8}{|l|}{ Age Range: } \\
\hline 18 to 29 & 0.31 & 0.30 & 0.30 & 0.30 & 0.31 & 0.31 & 0.69 \\
\hline 30 to 39 & 0.27 & 0.28 & 0.27 & 0.27 & 0.27 & 0.27 & 0.13 \\
\hline 40 to 49 & 0.42 & 0.41 & 0.42 & 0.42 & 0.42 & 0.42 & 0.69 \\
\hline \multicolumn{8}{|l|}{ Race: } \\
\hline Asian & 0.01 & 0.00 & 0.01 & 0.01 & 0.01 & 0.01 & 0.08 \\
\hline Black & 0.18 & 0.18 & 0.18 & 0.17 & 0.17 & 0.18 & 0.72 \\
\hline Hispanic & 0.04 & 0.04 & 0.04 & 0.05 & 0.04 & 0.04 & 0.49 \\
\hline Native American or Alaskan Native & 0.01 & 0.01 & 0.01 & 0.01 & 0.01 & 0.01 & 0.15 \\
\hline Other/Unknown & 0.44 & 0.44 & 0.44 & 0.44 & 0.45 & 0.43 & 0.07 \\
\hline White & 0.33 & 0.32 & 0.33 & 0.33 & 0.32 & 0.34 & 0.49 \\
\hline Female & 0.52 & 0.52 & 0.53 & 0.52 & 0.51 & 0.52 & 0.59 \\
\hline \multicolumn{8}{|c|}{ Panel C. Disability Information } \\
\hline \multicolumn{8}{|l|}{ Primary Diagnosis: } \\
\hline Infectious and Parasitic & 0.02 & 0.03 & 0.03 & 0.02 & 0.03 & 0.03 & 0.34 \\
\hline Neoplasms & 0.03 & 0.03 & 0.03 & 0.03 & 0.03 & 0.03 & 0.87 \\
\hline Endocrine & 0.01 & 0.01 & 0.01 & 0.01 & 0.01 & 0.01 & 0.76 \\
\hline Blood & 0.01 & 0.01 & 0.01 & 0.01 & 0.01 & 0.01 & 0.87 \\
\hline Autistic Disorders & 0.00 & 0.00 & 0.01 & 0.00 & 0.00 & 0.00 & 0.13 \\
\hline Developmental disorders & 0.00 & 0.00 & 0.00 & 0.00 & 0.01 & 0.00 & 0.81 \\
\hline Childhood and adolescent disorders N.E.C.* & 0.06 & 0.07 & 0.06 & 0.06 & 0.06 & 0.06 & 0.24 \\
\hline Intellectual disability & 0.22 & 0.21 & 0.21 & 0.22 & 0.21 & 0.22 & 0.31 \\
\hline Mood disorders & 0.03 & 0.03 & 0.03 & 0.03 & 0.03 & 0.03 & 0.40 \\
\hline Organic Mental Disorders & 0.09 & 0.09 & 0.09 & 0.09 & 0.10 & 0.09 & 0.18 \\
\hline Schizophrenia & 0.09 & 0.09 & 0.10 & 0.09 & 0.08 & 0.09 & 0.02 \\
\hline Other Mental disorders & 0.08 & 0.08 & 0.08 & 0.08 & 0.08 & 0.09 & 0.48 \\
\hline Nervous System & 0.04 & 0.04 & 0.04 & 0.04 & 0.05 & 0.04 & 0.34 \\
\hline Circulatory System & 0.02 & 0.02 & 0.02 & 0.02 & 0.02 & 0.02 & 0.47 \\
\hline Respiratory System & 0.02 & 0.02 & 0.02 & 0.02 & 0.02 & 0.02 & 0.87 \\
\hline Digestive System & 0.03 & 0.03 & 0.03 & 0.03 & 0.03 & 0.03 & 0.84 \\
\hline Genitourinary System & 0.00 & 0.00 & 0.00 & 0.01 & 0.01 & 0.00 & 0.32 \\
\hline Skin & 0.13 & 0.13 & 0.13 & 0.13 & 0.13 & 0.13 & 0.86 \\
\hline Musculoskeletal & 0.01 & 0.01 & 0.00 & 0.01 & 0.00 & 0.01 & 0.57 \\
\hline Congenital Anomalies & 0.04 & 0.04 & 0.04 & 0.04 & 0.03 & 0.04 & 0.84 \\
\hline Injuries & 0.00 & 0.00 & 0.00 & 0.00 & 0.00 & 0.00 & 0.02 \\
\hline Other & 0.02 & 0.02 & 0.02 & 0.02 & 0.02 & 0.02 & 0.21 \\
\hline Unknown & 0.01 & 0.01 & 0.01 & 0.01 & 0.01 & 0.01 & 0.31 \\
\hline Deaf & 0.01 & 0.01 & 0.01 & 0.01 & 0.01 & 0.01 & 0.56 \\
\hline Blind & 0.02 & 0.02 & 0.02 & 0.02 & 0.02 & 0.02 & 0.22 \\
\hline \multicolumn{8}{|l|}{ Medical diary type: } \\
\hline Medical Improvement Expected (MIE) & 0.07 & 0.06 & 0.06 & 0.07 & 0.07 & 0.07 & 0.54 \\
\hline Medical Improvement Possible (MIP) & 0.83 & 0.83 & 0.83 & 0.83 & 0.82 & 0.83 & 0.50 \\
\hline Medical Improvement Not Expected (MINE) & 0.11 & 0.11 & 0.10 & 0.10 & 0.11 & 0.10 & 0.71 \\
\hline
\end{tabular}


APPENDIX TABLE A.2

Balance Checks (Continued)

\begin{tabular}{|c|c|c|c|c|c|c|c|}
\hline & $\begin{array}{c}(1) \\
\text { Full } \\
\text { Sample }\end{array}$ & $\begin{array}{c}(2) \\
\text { Social } \\
\text { Framing }\end{array}$ & $\begin{array}{c}(3) \\
\text { Penalty } \\
\text { Framing }\end{array}$ & $\begin{array}{c}(4) \\
\text { Both } \\
\text { Framings }\end{array}$ & $\begin{array}{c}(5) \\
\text { No } \\
\text { Framing }\end{array}$ & $\begin{array}{c}(6) \\
\text { Control } \\
\text { (No Letter) }\end{array}$ & $\begin{array}{c}(7) \\
\text { F-test } \\
\text { p-value }\end{array}$ \\
\hline \multicolumn{8}{|c|}{ Panel D. State or Territory of Residence } \\
\hline \multicolumn{8}{|c|}{ State or Territory: } \\
\hline $\mathrm{AK}$ & 0.03 & 0.03 & 0.03 & 0.03 & 0.03 & 0.03 & 0.91 \\
\hline $\mathrm{AL}$ & 0.02 & 0.02 & 0.02 & 0.02 & 0.02 & 0.02 & 0.43 \\
\hline $\mathrm{AR}$ & 0.00 & 0.00 & 0.00 & 0.00 & 0.00 & 0.00 & 0.51 \\
\hline $\mathrm{AZ}$ & 0.01 & 0.01 & 0.01 & 0.01 & 0.02 & 0.02 & 0.25 \\
\hline $\mathrm{CA}$ & 0.01 & 0.01 & 0.01 & 0.01 & 0.01 & 0.01 & 0.89 \\
\hline $\mathrm{CO}$ & 0.01 & 0.01 & 0.01 & 0.01 & 0.01 & 0.01 & 0.39 \\
\hline $\mathrm{CT}$ & 0.00 & 0.00 & 0.00 & 0.01 & 0.00 & 0.00 & 0.09 \\
\hline $\mathrm{DC}$ & 0.00 & 0.00 & 0.00 & 0.00 & 0.00 & 0.00 & 0.05 \\
\hline $\mathrm{DE}$ & 0.06 & 0.06 & 0.06 & 0.06 & 0.06 & 0.06 & 0.71 \\
\hline FL & 0.04 & 0.04 & 0.04 & 0.04 & 0.04 & 0.04 & 0.97 \\
\hline GA & 0.00 & 0.00 & 0.00 & 0.00 & 0.00 & 0.00 & 0.84 \\
\hline HI & 0.01 & 0.01 & 0.01 & 0.01 & 0.01 & 0.01 & 0.50 \\
\hline IA & 0.00 & 0.00 & 0.00 & 0.01 & 0.01 & 0.00 & 0.73 \\
\hline ID & 0.04 & 0.03 & 0.04 & 0.04 & 0.03 & 0.04 & 0.51 \\
\hline IL & 0.03 & 0.03 & 0.03 & 0.02 & 0.03 & 0.02 & 0.76 \\
\hline IN & 0.01 & 0.01 & 0.01 & 0.01 & 0.01 & 0.01 & 0.95 \\
\hline $\mathrm{KS}$ & 0.03 & 0.03 & 0.03 & 0.03 & 0.03 & 0.03 & 0.53 \\
\hline $\mathrm{KY}$ & 0.03 & 0.03 & 0.03 & 0.03 & 0.03 & 0.03 & 0.22 \\
\hline LA & 0.03 & 0.03 & 0.03 & 0.03 & 0.03 & 0.03 & 0.88 \\
\hline MA & 0.02 & 0.02 & 0.02 & 0.02 & 0.02 & 0.02 & 0.08 \\
\hline MD & 0.01 & 0.01 & 0.01 & 0.01 & 0.01 & 0.01 & 0.96 \\
\hline $\mathrm{ME}$ & 0.05 & 0.04 & 0.05 & 0.04 & 0.05 & 0.05 & 0.46 \\
\hline MI & 0.01 & 0.01 & 0.01 & 0.01 & 0.01 & 0.01 & 0.90 \\
\hline $\mathrm{MN}$ & 0.03 & 0.03 & 0.03 & 0.03 & 0.03 & 0.03 & 0.23 \\
\hline MO & 0.02 & 0.02 & 0.02 & 0.02 & 0.02 & 0.02 & 0.53 \\
\hline MS & 0.00 & 0.00 & 0.00 & 0.00 & 0.00 & 0.00 & 0.30 \\
\hline $\mathrm{MT}$ & 0.00 & 0.00 & 0.00 & 0.00 & 0.00 & 0.00 & 0.48 \\
\hline $\mathrm{NC}$ & 0.00 & 0.00 & 0.00 & 0.00 & 0.00 & 0.00 & 0.80 \\
\hline ND & 0.01 & 0.01 & 0.01 & 0.01 & 0.01 & 0.01 & 0.93 \\
\hline $\mathrm{NE}$ & 0.01 & 0.01 & 0.01 & 0.01 & 0.01 & 0.01 & 0.27 \\
\hline $\mathrm{NH}$ & 0.02 & 0.01 & 0.02 & 0.02 & 0.02 & 0.02 & 0.18 \\
\hline NJ & 0.01 & 0.01 & 0.01 & 0.01 & 0.01 & 0.01 & 0.22 \\
\hline NM & 0.00 & 0.00 & 0.00 & 0.00 & 0.00 & 0.00 & 0.66 \\
\hline NV & 0.05 & 0.05 & 0.05 & 0.05 & 0.05 & 0.05 & 0.62 \\
\hline NY & 0.06 & 0.06 & 0.06 & 0.05 & 0.06 & 0.05 & 0.03 \\
\hline $\mathrm{OH}$ & 0.02 & 0.02 & 0.02 & 0.02 & 0.02 & 0.02 & 0.49 \\
\hline OK & 0.01 & 0.01 & 0.01 & 0.01 & 0.01 & 0.01 & 0.84 \\
\hline OR & 0.05 & 0.05 & 0.05 & 0.05 & 0.05 & 0.05 & 0.97 \\
\hline PA & 0.00 & 0.00 & 0.00 & 0.00 & 0.00 & 0.00 & 0.13 \\
\hline $\mathrm{RI}$ & 0.02 & 0.02 & 0.02 & 0.02 & 0.02 & 0.02 & 0.08 \\
\hline $\mathrm{SC}$ & 0.00 & 0.00 & 0.00 & 0.00 & 0.00 & 0.00 & 0.90 \\
\hline SD & 0.03 & 0.03 & 0.03 & 0.03 & 0.03 & 0.03 & 0.61 \\
\hline $\mathrm{TN}$ & 0.09 & 0.09 & 0.09 & 0.09 & 0.09 & 0.09 & 0.46 \\
\hline $\mathrm{TX}$ & 0.00 & 0.00 & 0.00 & 0.00 & 0.01 & 0.00 & 0.27 \\
\hline UT & 0.02 & 0.02 & 0.02 & 0.02 & 0.03 & 0.03 & 0.39 \\
\hline VA & 0.00 & 0.00 & 0.00 & 0.00 & 0.00 & 0.00 & 0.86 \\
\hline VT & 0.03 & 0.02 & 0.02 & 0.03 & 0.02 & 0.03 & 0.27 \\
\hline WA & 0.02 & 0.02 & 0.02 & 0.02 & 0.02 & 0.02 & 0.93 \\
\hline WI & 0.01 & 0.01 & 0.01 & 0.01 & 0.01 & 0.01 & 0.73 \\
\hline WV & 0.00 & 0.00 & 0.00 & 0.00 & 0.00 & 0.00 & 0.74 \\
\hline WY & 0.04 & 0.04 & 0.04 & 0.04 & 0.04 & 0.04 & 0.67 \\
\hline
\end{tabular}

NoTE.-Each row reports mean values for the corresponding variable for the full sample of SSI recipients in the experiment (column 1) and by experimental condition (columns 2-6). Panel A includes key overview variables of interest, Panel B includes basic demographic information, Panel $\mathrm{C}$ includes details on disability status and medical diary type, and Panel $\mathrm{D}$ includes details on the state or territory of residence. For each variable, the p-value of an F-test that the mean of the corresponding variable is the same across treatment groups is presented in column 7. Standard errors are reported in parentheses.

${ }^{\dagger}$ N.E.C. $=$ Not Elsewhere Classified. 
APPENDIX TABLE A.3

Reported Any Countable Earnings

\begin{tabular}{|c|c|c|c|c|c|c|c|c|c|}
\hline & \multicolumn{2}{|c|}{ Jan to Apr 2015} & \multicolumn{2}{|c|}{ May to Jul 2015} & \multicolumn{2}{|c|}{ May to Oct 2015} & May to Dec 2015 & \multicolumn{2}{|c|}{ Jan to Dec 2015} \\
\hline & (1) & $(2)$ & $(3)$ & $(4)$ & $(5)$ & $(6)$ & $(8)$ & $(9)$ & $(10)$ \\
\hline \multicolumn{10}{|c|}{ Panel A. SSR Monthly Extract from April 2015} \\
\hline Received Letter & $\begin{array}{c}0.0018^{*} \\
(0.0010)\end{array}$ & $\begin{array}{c}0.0018^{*} \\
(0.0010)\end{array}$ & & & & & & & \\
\hline Social Framing & $\begin{array}{c}-0.0010 \\
(0.0010)\end{array}$ & $\begin{array}{c}-0.0010 \\
(0.0010)\end{array}$ & & & & & & & \\
\hline Penalty Framing & $\begin{array}{c}0.0003 \\
(0.0010)\end{array}$ & $\begin{array}{c}0.0003 \\
(0.0010)\end{array}$ & & & & & & & \\
\hline Both Framings & $\begin{array}{c}0.0007 \\
(0.0015)\end{array}$ & $\begin{array}{c}0.0008 \\
(0.0015)\end{array}$ & & & & & & & \\
\hline Constant & $\begin{array}{l}0.0041^{* * *} \\
(0.0007)\end{array}$ & $\begin{array}{c}-0.0073^{* *} \\
(0.0032)\end{array}$ & & & & & & & \\
\hline R-squared & 0.000 & 0.006 & & & & & & & \\
\hline Prob $>$ F & 0.615 & 0.592 & & & & & & & \\
\hline \multicolumn{10}{|c|}{ Panel B. SSR Monthly Extract from July 2015} \\
\hline Received Letter & $\begin{array}{c}0.0032^{* *} \\
(0.0015)\end{array}$ & $\begin{array}{l}0.0033^{* *} \\
(0.0015)\end{array}$ & $\begin{array}{c}0.0034^{* *} \\
(0.0016)\end{array}$ & $\begin{array}{c}0.0034^{* *} \\
(0.0016)\end{array}$ & & & & & \\
\hline Social Framing & $\begin{array}{c}0.0000 \\
(0.0015)\end{array}$ & $\begin{array}{c}-0.0001 \\
(0.0015)\end{array}$ & $\begin{array}{c}-0.0006 \\
(0.0016)\end{array}$ & $\begin{array}{c}-0.0005 \\
(0.0016)\end{array}$ & & & & & \\
\hline Penalty Framing & $\begin{array}{c}0.0006 \\
(0.0015)\end{array}$ & $\begin{array}{c}0.0005 \\
(0.0015)\end{array}$ & $\begin{array}{c}-0.0002 \\
(0.0016)\end{array}$ & $\begin{array}{c}-0.0001 \\
(0.0016)\end{array}$ & & & & & \\
\hline Both Framings & $\begin{array}{c}0.0002 \\
(0.0021)\end{array}$ & $\begin{array}{c}0.0005 \\
(0.0021)\end{array}$ & $\begin{array}{c}0.0013 \\
(0.0022)\end{array}$ & $\begin{array}{c}0.0013 \\
(0.0022)\end{array}$ & & & & & \\
\hline Constant & $\begin{array}{l}0.0087^{* * * *} \\
(0.0011)\end{array}$ & $\begin{array}{c}-0.0110^{* *} \\
(0.0046)\end{array}$ & $\begin{array}{l}0.0097^{* * *} \\
(0.0011)\end{array}$ & $\begin{array}{c}-0.0079^{*} \\
(0.0048)\end{array}$ & & & & & \\
\hline R-squared & 0.000 & 0.009 & 0.000 & 0.009 & & & & & \\
\hline Prob $>$ F & 0.930 & 0.904 & 0.916 & 0.905 & & & & & \\
\hline \multicolumn{10}{|c|}{ Panel C. SSR Monthly Extract from October 2015} \\
\hline Received Letter & $\begin{array}{c}0.0008 \\
(0.0017)\end{array}$ & $\begin{array}{c}0.0009 \\
(0.0017)\end{array}$ & $\begin{array}{c}0.0021 \\
(0.0018)\end{array}$ & $\begin{array}{c}0.0021 \\
(0.0018)\end{array}$ & $\begin{array}{c}0.0022 \\
(0.0020)\end{array}$ & $\begin{array}{c}0.0022 \\
(0.0020)\end{array}$ & & & \\
\hline Social Framing & $\begin{array}{c}-0.0004 \\
(0.0017)\end{array}$ & $\begin{array}{c}-0.0005 \\
(0.0017)\end{array}$ & $\begin{array}{c}-0.0003 \\
(0.0018)\end{array}$ & $\begin{array}{c}-0.0002 \\
(0.0018)\end{array}$ & $\begin{array}{c}0.0004 \\
(0.0020)\end{array}$ & $\begin{array}{c}0.0006 \\
(0.0020)\end{array}$ & & & \\
\hline Penalty Framing & $\begin{array}{c}0.0015 \\
(0.0017)\end{array}$ & $\begin{array}{c}0.0015 \\
(0.0017)\end{array}$ & $\begin{array}{c}0.0005 \\
(0.0018)\end{array}$ & $\begin{array}{c}0.0007 \\
(0.0018)\end{array}$ & $\begin{array}{c}-0.0002 \\
(0.0020)\end{array}$ & $\begin{array}{c}-0.0001 \\
(0.0020)\end{array}$ & & & \\
\hline Both Framings & $\begin{array}{c}0.0013 \\
(0.0024)\end{array}$ & $\begin{array}{c}0.0015 \\
(0.0024)\end{array}$ & $\begin{array}{c}0.0020 \\
(0.0026)\end{array}$ & $\begin{array}{c}0.0019 \\
(0.0026)\end{array}$ & $\begin{array}{c}0.0024 \\
(0.0029)\end{array}$ & $\begin{array}{c}0.0024 \\
(0.0028)\end{array}$ & & & \\
\hline Constant & $\begin{array}{l}0.0135^{* * *} \\
(0.0012)\end{array}$ & $\begin{array}{c}-0.0091^{*} \\
(0.0052)\end{array}$ & $\begin{array}{l}0.0146^{* * *} \\
(0.0013)\end{array}$ & $\begin{array}{c}-0.0054 \\
(0.0055)\end{array}$ & $\begin{array}{l}0.0185^{* * *} \\
(0.0014)\end{array}$ & $\begin{array}{c}-0.0077 \\
(0.0061)\end{array}$ & & & \\
\hline R-squared & 0.000 & 0.011 & 0.000 & 0.012 & 0.000 & 0.014 & & & \\
\hline Prob $>$ F & 0.322 & 0.257 & 0.518 & 0.456 & 0.484 & 0.420 & & & \\
\hline
\end{tabular}


APPENDIX TABLE A.3

Reported Any Countable Earnings (Continued)

\begin{tabular}{|c|c|c|c|c|c|c|c|c|c|c|}
\hline & \multicolumn{2}{|c|}{ Jan to Apr 2015} & \multicolumn{2}{|c|}{ May to Jul 2015} & \multicolumn{2}{|c|}{ May to Oct 2015} & \multicolumn{2}{|c|}{ May to Dec 2015} & \multicolumn{2}{|c|}{ Jan to Dec 2015} \\
\hline & (1) & $(2)$ & $(3)$ & (4) & $(5)$ & (6) & (7) & (8) & (9) & (10) \\
\hline \multicolumn{11}{|c|}{ Panel C. SSR Monthly Extract from December 2015} \\
\hline Received Letter & $\begin{array}{c}-0.0002 \\
(0.0019)\end{array}$ & $\begin{array}{c}-0.0001 \\
(0.0019)\end{array}$ & $\begin{array}{c}0.0013 \\
(0.0020)\end{array}$ & $\begin{array}{c}0.0013 \\
(0.0020)\end{array}$ & $\begin{array}{c}0.0009 \\
(0.0023)\end{array}$ & $\begin{array}{c}0.0010 \\
(0.0023)\end{array}$ & $\begin{array}{c}0.0015 \\
(0.0023)\end{array}$ & $\begin{array}{c}0.0016 \\
(0.0023)\end{array}$ & $\begin{array}{c}0.0011 \\
(0.0025)\end{array}$ & $\begin{array}{c}0.0012 \\
(0.0025)\end{array}$ \\
\hline Social Framing & $\begin{array}{c}0.0006 \\
(0.0019)\end{array}$ & $\begin{array}{c}0.0005 \\
(0.0019)\end{array}$ & $\begin{array}{c}0.0000 \\
(0.0020)\end{array}$ & $\begin{array}{c}0.0001 \\
(0.0020)\end{array}$ & $\begin{array}{c}0.0007 \\
(0.0023)\end{array}$ & $\begin{array}{c}0.0008 \\
(0.0022)\end{array}$ & $\begin{array}{c}0.0004 \\
(0.0023)\end{array}$ & $\begin{array}{c}0.0005 \\
(0.0023)\end{array}$ & $\begin{array}{c}0.0013 \\
(0.0025)\end{array}$ & $\begin{array}{c}0.0013 \\
(0.0025)\end{array}$ \\
\hline Penalty Framing & $\begin{array}{c}0.0024 \\
(0.0019)\end{array}$ & $\begin{array}{c}0.0024 \\
(0.0019)\end{array}$ & $\begin{array}{c}0.0009 \\
(0.0020)\end{array}$ & $\begin{array}{c}0.0010 \\
(0.0020)\end{array}$ & $\begin{array}{c}0.0009 \\
(0.0023)\end{array}$ & $\begin{array}{c}0.0010 \\
(0.0022)\end{array}$ & $\begin{array}{c}0.0005 \\
(0.0023)\end{array}$ & $\begin{array}{c}0.0006 \\
(0.0023)\end{array}$ & $\begin{array}{c}0.0024 \\
(0.0025)\end{array}$ & $\begin{array}{c}0.0024 \\
(0.0025)\end{array}$ \\
\hline Both Framings & $\begin{array}{c}0.0005 \\
(0.0027)\end{array}$ & $\begin{array}{c}0.0008 \\
(0.0027)\end{array}$ & $\begin{array}{c}0.0017 \\
(0.0028)\end{array}$ & $\begin{array}{c}0.0017 \\
(0.0028)\end{array}$ & $\begin{array}{c}0.0024 \\
(0.0032)\end{array}$ & $\begin{array}{c}0.0025 \\
(0.0032)\end{array}$ & $\begin{array}{c}0.0023 \\
(0.0033)\end{array}$ & $\begin{array}{c}0.0023 \\
(0.0033)\end{array}$ & $\begin{array}{c}0.0011 \\
(0.0036)\end{array}$ & $\begin{array}{c}0.0014 \\
(0.0036)\end{array}$ \\
\hline Constant & $\begin{array}{l}0.0173^{* * *} \\
(0.0013)\end{array}$ & $\begin{array}{c}-0.0116^{* *} \\
(0.0058)\end{array}$ & $\begin{array}{l}0.0183^{* * *} \\
(0.0014)\end{array}$ & $\begin{array}{c}-0.0065 \\
(0.0060)\end{array}$ & $\begin{array}{l}0.0245^{* * *} \\
(0.0016)\end{array}$ & $\begin{array}{r}-0.0120^{*} \\
(0.0069)\end{array}$ & $\begin{array}{l}0.0259^{* * *} \\
(0.0016)\end{array}$ & $\begin{array}{c}-0.0102 \\
(0.0071)\end{array}$ & $\begin{array}{l}0.0306^{* * *} \\
(0.0018)\end{array}$ & $\begin{array}{c}-0.0160^{* *} \\
(0.0077)\end{array}$ \\
\hline R-squared & 0.000 & 0.012 & 0.000 & 0.012 & 0.000 & 0.017 & 0.000 & 0.017 & 0.000 & 0.019 \\
\hline Prob $>$ F & 0.230 & 0.178 & 0.513 & 0.442 & 0.297 & 0.245 & 0.498 & 0.435 & 0.275 & 0.216 \\
\hline $\begin{array}{l}\text { Controls } \\
\text { Observations }\end{array}$ & 50,000 & $\begin{array}{c}\text { Yes } \\
50,000\end{array}$ & 50,000 & $\begin{array}{c}\text { Yes } \\
50,000\end{array}$ & 50,000 & $\begin{array}{c}\text { Yes } \\
50,000\end{array}$ & 50,000 & $\begin{array}{c}\text { Yes } \\
50,000\end{array}$ & 50,000 & $\begin{array}{c}\text { Yes } \\
50,000\end{array}$ \\
\hline
\end{tabular}

NoTE.-This table reports estimates of the aggregate effect of receiving a letter reminding SSI recipients of their wage reporting responsibilities on the likelihood of reporting any countable earnings. Each column presents a separate regression where the dependent variable is an indicator for whether the recipient reported any countable earnings. Controls include age, gender, dummies for race/ethnicity, state or territory of residence, years on the SSI program, an indicator for whether the recipient is permanently disabled, and indicators for the primary disability diagnosis. The time horizon for the dependent variable varies by column. Columns 1 and 2 report estimates where the time horizon for the dependent variable is the three months prior to and including the month when the treatment letters were mailed (1.e., whether any countable earnings were reported for January 2015 - April 2015); Columns 3 and 4 report estimates where the time horizon is the three months post treatment (May 2015 - July 2015); Columns 5 and 6 report estimates where the time horizon is the six months post treatment (May 2015 - Oct 2015); Columns 7 and 8 report estimates where the time horizon is post treatment through the year end (May 2015 - Dec 2015); and Columns 9 and 10 report estimates where the time horizon is the full calendar year for 2015 . Each panel presents estimates using a different extract of the SSR as it existed at the end of the indicated month. For example, Panel A reports estimates using an extract of the SSR data as it existed at the end of April 2015. Coefficients are reported for a "Received Letter" indicator denoting whether the recipient received a letter (experimental mailing) from the SSA; a "Social Framing" indicator denoting whether the letter contained social framing; a "Penalty Framing" indicator for whether the letter contained the penalty framing; and a "Both Framings" indicator for whether the letter contained both the social framing and the penalty framing. The second row at the bottom of each panel reports p-values from an F-test of whether there is no differential effect of the behavioral framing. Significance levels $10 \%, 5 \%$, and $1 \%$ are denoted by $*, * *$, and ${ }^{* * *}$, respectively. 
APPENDIX TABLE A.4

Amount Of Countable Earnings Reported

\begin{tabular}{|c|c|c|c|c|c|c|c|c|c|}
\hline & \multicolumn{2}{|c|}{ Jan to Apr 2015} & \multicolumn{2}{|c|}{ May to Jul 2015} & \multicolumn{2}{|c|}{ May to Oct 2015} & May to Dec 2015 & \multicolumn{2}{|c|}{ Jan to Dec 2015} \\
\hline & $(1)$ & $(2)$ & $(3)$ & $(4)$ & $(5)$ & $(6)$ & $(7)$ & $(9)$ & $(10)$ \\
\hline \multicolumn{10}{|c|}{ Panel A. SSR Monthly Extract from April 2015} \\
\hline Received Letter & $\begin{array}{l}2.6990^{* *} \\
(1.3650)\end{array}$ & $\begin{array}{c}2.6577^{*} \\
(1.3659)\end{array}$ & & & & & & & \\
\hline Social Framing & $\begin{array}{c}0.4075 \\
(1.3650)\end{array}$ & $\begin{array}{c}0.4401 \\
(1.3658)\end{array}$ & & & & & & & \\
\hline Penalty Framing & $\begin{array}{c}-1.4978 \\
(1.3650)\end{array}$ & $\begin{array}{c}-1.5008 \\
(1.3658)\end{array}$ & & & & & & & \\
\hline Both Framings & $\begin{array}{c}-0.7209 \\
(1.9305)\end{array}$ & $\begin{array}{c}-0.6891 \\
(1.9314)\end{array}$ & & & & & & & \\
\hline Constant & $\begin{array}{l}2.6654^{* * * *} \\
(0.9652)\end{array}$ & $\begin{array}{r}-7.2477^{*} \\
(4.1635)\end{array}$ & & & & & & & \\
\hline R-squared & 0.000 & 0.003 & & & & & & & \\
\hline Prob $>$ F & 0.278 & 0.285 & & & & & & & \\
\hline \multicolumn{10}{|c|}{ Panel B. SSR Monthly Extract from July 2015} \\
\hline Received Letter & $\begin{array}{l}6.4944^{* * * *} \\
(2.1054)\end{array}$ & $\begin{array}{l}6.6912^{* * *} \\
(2.1056)\end{array}$ & $\begin{array}{l}6.8129^{* * *} \\
(2.2154)\end{array}$ & $\begin{array}{l}\text { 6.9151*** } \\
(2.2137)\end{array}$ & & & & & \\
\hline Social Framing & $\begin{array}{c}-0.1852 \\
(2.1054)\end{array}$ & $\begin{array}{c}-0.2594 \\
(2.1054)\end{array}$ & $\begin{array}{c}-2.9976 \\
(2.2154)\end{array}$ & $\begin{array}{c}-2.8936 \\
(2.2135)\end{array}$ & & & & & \\
\hline Penalty Framing & $\begin{array}{c}-1.3384 \\
(2.1054)\end{array}$ & $\begin{array}{c}-1.4030 \\
(2.1054)\end{array}$ & $\begin{array}{r}-4.2972^{*} \\
(2.2154)\end{array}$ & $\begin{array}{c}-4.1673^{*} \\
(2.2135)\end{array}$ & & & & & \\
\hline Both Framings & $\begin{array}{c}-0.1005 \\
(2.9775)\end{array}$ & $\begin{array}{c}0.0301 \\
(2.9773)\end{array}$ & $\begin{array}{c}6.1075^{*} \\
(3.1331)\end{array}$ & $\begin{array}{c}6.0007^{*} \\
(3.1302)\end{array}$ & & & & & \\
\hline Constant & $\begin{array}{l}5.4218^{* * * *} \\
(1.4888)\end{array}$ & $\begin{array}{r}-11.0722^{*} \\
(6.4182)\end{array}$ & $\begin{array}{l}8.8803^{* * *} \\
(1.5665)\end{array}$ & $\begin{array}{c}-3.5737 \\
(6.7479)\end{array}$ & & & & & \\
\hline R-squared & 0.000 & 0.004 & 0.000 & 0.006 & & & & & \\
\hline Prob > F & 0.826 & 0.826 & 0.219 & 0.237 & & & & & \\
\hline \multicolumn{10}{|c|}{ Panel C. SSR Monthly Extract from October 2015} \\
\hline Received Letter & $\begin{array}{c}3.7914 \\
(2.6222)\end{array}$ & $\begin{array}{c}3.9276 \\
(2.6214)\end{array}$ & $\begin{array}{c}4.1966 \\
(2.8925)\end{array}$ & $\begin{array}{c}4.2363 \\
(2.8897)\end{array}$ & $\begin{array}{c}6.6238 \\
(5.6736)\end{array}$ & $\begin{array}{c}6.7063 \\
(5.6656)\end{array}$ & & & \\
\hline Social Framing & $\begin{array}{c}-1.0275 \\
(2.6222)\end{array}$ & $\begin{array}{c}-1.0049 \\
(2.6212)\end{array}$ & $\begin{array}{c}-4.7418 \\
(2.8925)\end{array}$ & $\begin{array}{c}-4.5826 \\
(2.8895)\end{array}$ & $\begin{array}{c}-8.6331 \\
(5.6736)\end{array}$ & $\begin{array}{r}-8.3116 \\
(5.6652)\end{array}$ & & & \\
\hline Penalty Framing & $\begin{array}{c}0.3456 \\
(2.6222)\end{array}$ & $\begin{array}{c}0.3717 \\
(2.6212)\end{array}$ & $\begin{array}{c}-4.0708 \\
(2.8925)\end{array}$ & $\begin{array}{c}-3.7852 \\
(2.8894)\end{array}$ & $\begin{array}{c}-9.4664^{*} \\
(5.6736)\end{array}$ & $\begin{array}{c}-9.0571 \\
(5.6651)\end{array}$ & & & \\
\hline Both Framings & $\begin{array}{c}3.0164 \\
(3.7083)\end{array}$ & $\begin{array}{c}3.0680 \\
(3.7067)\end{array}$ & $\begin{array}{l}11.0238^{* * *} \\
(4.0906)\end{array}$ & $\begin{array}{l}10.7503^{* * * *} \\
(4.0861)\end{array}$ & $\begin{array}{l}22.9915^{* * *} \\
(8.0237)\end{array}$ & $\begin{array}{l}22.6125^{* * *} \\
(8.0113)\end{array}$ & & & \\
\hline Constant & $\begin{array}{l}10.8549^{* * * *} \\
(1.8541)\end{array}$ & $\begin{array}{c}2.1002 \\
(7.9907) \\
\end{array}$ & $\begin{array}{l}15.2602^{* * *} \\
(2.0453)\end{array}$ & $\begin{array}{c}6.8466 \\
(8.8084)\end{array}$ & $\begin{array}{l}34.3017^{* * *} \\
(4.0119)\end{array}$ & $\begin{array}{c}15.9622 \\
(17.2701)\end{array}$ & & & \\
\hline R-squared & 0.000 & 0.004 & 0.000 & 0.006 & 0.000 & 0.0074 & & & \\
\hline Prob $>$ F & 0.631 & 0.610 & 0.048 & 0.053 & 0.030 & 0.032 & & & \\
\hline
\end{tabular}


APPENDIX TABLE A.4

Amount Of Countable Earnings Reported (Continued)

\begin{tabular}{|c|c|c|c|c|c|c|c|c|c|c|}
\hline & \multicolumn{2}{|c|}{ Jan to Apr 2015} & \multicolumn{2}{|c|}{ May to Jul 2015} & \multicolumn{2}{|c|}{ May to Oct 2015} & \multicolumn{2}{|c|}{ May to Dec 2015} & \multicolumn{2}{|c|}{ Jan to Dec 2015} \\
\hline & (1) & $(2)$ & $(3)$ & $(4)$ & $(5)$ & $(6)$ & $(7)$ & $(8)$ & (9) & $(10)$ \\
\hline \multicolumn{11}{|c|}{ Panel D. SSR Monthly Extract from December 2015} \\
\hline Received Letter & $\begin{array}{c}2.8108 \\
(2.8126)\end{array}$ & $\begin{array}{c}2.9288 \\
(2.8111)\end{array}$ & $\begin{array}{c}3.7809 \\
(3.0122)\end{array}$ & $\begin{array}{c}3.8344 \\
(3.0088)\end{array}$ & $\begin{array}{c}5.2208 \\
(5.8731)\end{array}$ & $\begin{array}{c}5.3192 \\
(5.8630)\end{array}$ & $\begin{array}{c}5.3906 \\
(7.7518)\end{array}$ & $\begin{array}{c}5.5147 \\
(7.7365)\end{array}$ & $\begin{array}{c}8.2014 \\
(9.6609)\end{array}$ & $\begin{array}{l}8.4435 \\
(9.6417)\end{array}$ \\
\hline Social Framing & $\begin{array}{c}0.1440 \\
(2.8126)\end{array}$ & $\begin{array}{c}0.1310 \\
(2.8108)\end{array}$ & $\begin{array}{c}-3.5718 \\
(3.0122)\end{array}$ & $\begin{array}{c}-3.4551 \\
(3.0085)\end{array}$ & $\begin{array}{c}-8.1275 \\
(5.8731)\end{array}$ & $\begin{array}{c}-7.8468 \\
(5.8625)\end{array}$ & $\begin{array}{r}-10.6647 \\
(7.7518)\end{array}$ & $\begin{array}{r}-10.2531 \\
(7.7358)\end{array}$ & $\begin{array}{r}-10.5207 \\
(9.6609)\end{array}$ & $\begin{array}{r}-10.1221 \\
(9.6409)\end{array}$ \\
\hline Penalty Framing & $\begin{array}{c}1.0860 \\
(2.8126)\end{array}$ & $\begin{array}{l}1.1221 \\
(2.8108)\end{array}$ & $\begin{array}{c}-3.4299 \\
(3.0122)\end{array}$ & $\begin{array}{c}-3.1588 \\
(3.0085)\end{array}$ & $\begin{array}{c}-6.6226 \\
(5.8731)\end{array}$ & $\begin{array}{c}-6.2240 \\
(5.8624)\end{array}$ & $\begin{array}{c}-8.4554 \\
(7.7518)\end{array}$ & $\begin{array}{r}-7.9549 \\
(7.7358)\end{array}$ & $\begin{array}{r}-7.3694 \\
(9.6609)\end{array}$ & $\begin{array}{c}-6.8328 \\
(9.6408)\end{array}$ \\
\hline Both Framings & $\begin{array}{c}2.5415 \\
(3.9776)\end{array}$ & $\begin{array}{c}2.5849 \\
(3.9749)\end{array}$ & $\begin{array}{l}10.0080^{* *} \\
(4.2599)\end{array}$ & $\begin{array}{c}9.7476^{* *} \\
(4.2544)\end{array}$ & $\begin{array}{l}21.6947^{* * *} \\
(8.3058)\end{array}$ & $\begin{array}{l}21.3292^{* *} \\
(8.2903)\end{array}$ & $\begin{array}{l}27.6361^{* *} \\
(10.9627)\end{array}$ & $\begin{array}{c}27.1961^{* *} \\
(10.9395)\end{array}$ & $\begin{array}{l}30.1776^{* *} \\
(13.6625)\end{array}$ & $\begin{array}{l}29.7810^{* *} \\
(13.6335)\end{array}$ \\
\hline Constant & $\begin{array}{l}13.8605^{* * *} \\
(1.9888)\end{array}$ & $\begin{array}{c}-1.4161 \\
(8.5687)\end{array}$ & $\begin{array}{l}17.3455^{* * *} \\
(2.1300)\end{array}$ & $\begin{array}{c}5.1331 \\
(9.1713) \\
\end{array}$ & $\begin{array}{l}39.3275^{* * *} \\
(4.1529)\end{array}$ & $\begin{array}{c}11.6969 \\
(17.8716)\end{array}$ & $\begin{array}{l}55.0110^{* * *} \\
(5.4814)\end{array}$ & $\begin{array}{c}15.6366 \\
(23.5825)\end{array}$ & $\begin{array}{l}68.8715^{* * *} \\
(6.8313)\end{array}$ & $\begin{array}{c}14.2205 \\
(29.3900)\end{array}$ \\
\hline R-squared & 0.000 & 0.005 & 0.000 & 0.006 & 0.000 & 0.007 & 0.000 & 0.008 & 0.000 & 0.008 \\
\hline Prob $>$ F & 0.509 & 0.491 & 0.089 & 0.096 & 0.041 & 0.042 & 0.054 & 0.055 & 0.086 & 0.084 \\
\hline $\begin{array}{l}\text { Controls } \\
\text { Observations }\end{array}$ & 50,000 & $\begin{array}{c}\text { Yes } \\
50,000\end{array}$ & 50,000 & $\begin{array}{c}\text { Yes } \\
50,000\end{array}$ & 50,000 & $\begin{array}{c}\text { Yes } \\
50,000\end{array}$ & 50,000 & $\begin{array}{c}\text { Yes } \\
50,000\end{array}$ & 50,000 & $\begin{array}{c}\text { Yes } \\
50,000\end{array}$ \\
\hline
\end{tabular}

NotE.- This table reports estimates of the aggregate effect of receiving a letter reminding SSI recipients of their wage reporting responsibilities on the dollar amount of countable earnings reported. Each column presents a separate regression where the dependent variable is the amount of countable earnings reported by the recipient. Controls include age, gender, dummies for race/ethnicity, state or territory of residence, years on the SSI program, an indicator for whether the recipient is permanently disabled, and indicators for the primary disability diagnosis. The time horizon for the dependent variable varies by column. Columns 1 and 2 report estimates where the time horizon for the dependent variable is the three months prior to and including the month when the treatment letters were mailed (i.e., whether any countable earnings were reported for January 2015 - April 2015); Columns 3 and 4 report estimates where the time horizon is the three months post treatment (May 2015 - July 2015); Columns 5 and 6 report estimates where the time horizon is the six months post treatment (May 2015 - Oct 2015); Columns 7 and 8 report estimates where the time horizon is post treatment through the year end (May 2015 - Dec 2015); and Columns 9 and 10 report estimates where the time horizon is the full calendar year for 2015. Each panel presents estimates using a different extract of the SSR data as it existed at the end of the indicated month. For example, Panel A reports estimates using an extract of the SSR data as it existed at the end of April 2015. Coefficients are reported for a "Received Letter" indicator denoting whether the recipient received a letter (experimental mailing) from the SSA; a "Social Framing" indicator denoting whether the letter contained social framing; a "Penalty Framing" indicator for whether the letter contained the penalty framing; and a "Both Framings" indicator for whether the letter contained both the social framing and the penalty framing, The second row at the bottom of each panel reports p-values from an F-test of whether there is no differential effect of the behavioral framing. Significance levels $10 \%, 5 \%$, and $1 \%$ are denoted by *,** and ${ }^{* * *}$, respectively. 
APPENDIX TABLE A.5

LABOR SUPPLY EFFECTS

\begin{tabular}{|c|c|c|c|c|c|c|}
\hline & \multicolumn{2}{|c|}{ Employed } & \multicolumn{2}{|c|}{ Amount of W2 Earnings } & \multicolumn{2}{|c|}{ Number of Employers } \\
\hline & (1) & $(2)$ & $(3)$ & (4) & $(5)$ & (6) \\
\hline \multirow[t]{2}{*}{ Received Letter } & 0.0017 & 0.0019 & 18.3238 & 22.0459 & 0.0015 & 0.0020 \\
\hline & $(0.0036)$ & $(0.0036)$ & $(31.3254)$ & $(31.1291)$ & $(0.0067)$ & $(0.0065)$ \\
\hline \multirow[t]{2}{*}{ Constant } & $0.1194^{* * *}$ & $-0.0359^{* * *}$ & $569.7559^{* * *}$ & -59.4671 & $0.1823^{* * *}$ & $-0.0894^{* * *}$ \\
\hline & $(0.0033)$ & $(0.0137)$ & $(28.0183)$ & $(120.0292)$ & $(0.0060)$ & $(0.0252)$ \\
\hline R-squared & 0.000 & 0.047 & 0.000 & 0.016 & 0.000 & 0.041 \\
\hline Prob $>$ F & 0.629 & 0.613 & 0.840 & 0.790 & 0.268 & 0.239 \\
\hline Controls & & Yes & & Yes & & Yes \\
\hline Observations & 50,000 & 50,000 & 50,000 & 50,000 & 50,000 & 50,000 \\
\hline
\end{tabular}

NOTE.-This table reports estimates of the aggregate effect of receiving a letter reminding SSI recipients of their wage reporting responsibilities on the likelihood of being employed (Columns 1 and 2), the amount of reported W2 earnings (Columns 3 and 4), and the number of employers (Columns 5 and 6). Each column presents a separate regression where the dependent variable is given by the header of the column. Controls include age, gender, dummies for race/ethnicity, state or territory of residence, years on the SSI program, an indicator for whether the recipient is permanently disabled, and indicators for the primary disability diagnosis. All regressions use annual earnings information as reported on an individual's W2 Form for 2015 from the MEF data. Coefficients are reported for a "Received Letter" indicator denoting whether the recipient received a letter (experimental mailing) from the SSA. The table also reports p-values from an F-test of whether there is no differential effect of the behavioral framing. Significance levels $10 \%, 5 \%$, and $1 \%$ are denoted by $*, * *$, and ${ }^{* * *}$, respectively. 